\title{
Transforming Growth Factor- $\beta$ Signaling in Thoracic Aortic Aneurysm Development: A Paradox in Pathogenesis
}

\author{
Jeffrey A. Jones ${ }^{a, b}$ Francis G. Spinale ${ }^{a, b}$ John S. Ikonomidis ${ }^{a}$ \\ a Department of Surgery, Division of Cardiothoracic Surgery Research, Medical University of South Carolina, and \\ ${ }^{b}$ Ralph H. Johnson Veterans Affairs Medical Center, Charleston, S.C., USA
}

\section{Key Words}

TGF- $\beta \cdot$ Aneurysm $\cdot$ Signal transduction $\cdot$ Extracellular matrix $\cdot$ Remodeling

\begin{abstract}
Thoracic aortic aneurysms (TAAs) are potentially devastating, and due to their asymptomatic behavior, pose a serious health risk characterized by the lack of medical treatment options and high rates of surgical morbidity and mortality. Independent of the inciting stimuli (biochemical/mechanical), TAA development proceeds by a multifactorial process influenced by both cellular and extracellular mechanisms, resulting in alterations of the structure and composition of the vascular extracellular matrix (ECM). While the role of enhanced ECM proteolysis in TAA formation remains undisputed, little attention has been focused on the upstream signaling events that drive the remodeling process. Recent evidence highlighting the dysregulation of transforming growth factor- $\beta$ (TGF- $\beta$ ) signaling in ascending TAAs from Marfan syndrome patients has stimulated an interest in this intracellular signaling pathway. However, paradoxical discoveries have implicated both enhanced TGF- $\beta$ signaling and loss of function TGF- $\beta$ receptor mutations, in aneurysm formation; obfuscating a clear functional role for TGF- $\beta$ in aneurysm development. In an effort to elucidate this sub-
\end{abstract}

ject, TGF- $\beta$ signaling and its role in vascular remodeling and pathology will be reviewed, with the aim of identifying potential mechanisms of how TGF- $\beta$ signaling may contribute to the formation and progression of TAA.

Copyright $\odot 2008$ S. Karger AG, Basel

\section{Introduction}

Thoracic aortic aneurysms (TAAs) develop as a result of maladaptive remodeling of the vascular extracellular matrix (ECM). These malignant alterations cause weakening of the aortic ultrastructure and lead to an increased propensity for dilatation, dissection, and rupture $[1,2]$. ECM remodeling occurs by a highly regulated process involving both intracellular and extracellular mechanisms that function to balance matrix deposition and matrix degradation in order to maintain the structural integrity of the vascular wall $[3,4]$. In the aneurysmal aorta, this balance is disrupted in favor of enhanced proteolysis, which results in the pathological remodeling of the vascular ECM $[2,5]$. While the majority of previous studies have focused on the dysregulation of extracellular

This work was supported by NIH/NHLBI R01 HL075488-04.

\section{KARGER}

() 2008 S. Karger AG, Basel

Fax +41613061234

E-Mail karger@karger.ch

www.karger.com
Accessible online at:

www.karger.com/jvr
Dr. Jeffrey A. Jones

Division of Cardiothoracic Surgery Research, Department of Surgery

Medical University of South Carolina, Strom Thurmond Research Building

114 Doughty Street, Suite 625, Charleston, SC 29425 (USA)

Tel. +1 843876 5186, Fax +1 843876 5187, E-Mail jonesja@musc.edu 
protease systems in aneurysm formation, little attention has been focused on the small-molecule mediators that drive multiple signaling pathways upstream and regulate the remodeling process. One upstream signaling protein known to alter the structure and composition of the ECM, and known to play an important role in vascular remodeling is transforming growth factor- $\beta$ (TGF- $\beta)[6$, 7]. TGF- $\beta$ is a member of a superfamily of ligands and receptors that include the TGF- $\beta$, bone morphogenetic proteins, and the activins/inhibins. These soluble peptide growth factors are produced by multiple cell types and participate in a wide array of cellular responses including: proliferation, angiogenesis, differentiation, apoptosis, inflammation, and wound healing [8-10]. While TGF- $\beta$ is probably best known for its role in matrix deposition (e.g. collagen synthesis) related to fibrotic disease [7], TGF- $\beta$ has also been shown to regulate alternate pathways that can lead to matrix degradation [11-14]. Recent studies demonstrating altered TGF- $\beta$ signaling in aneurysm formation have sparked an interest in how a well-known profibrotic growth factor can participate in a pathological process that is characterized by extensive matrix degradation. Thus, the goal of the present article is to review both the classical and alternative pathways of TGF- $\beta$ signaling, its role in regulating ECM remodeling, and to propose mechanisms based on how this complex signaling pathway may be involved in TAA development.

\section{Thoracic Aortic Aneurysms}

Each year 15,000 lives are claimed by aortic aneurysmal disease, making it the 13th leading cause of death in people 55 years of age or older in the United States (National Center for Health Statistics, 2000). A TAA is defined as a localized dilatation of the supradiaphragmatic aorta exceeding 1.5 times its original diameter [15]. Anatomically, ascending TAAs are the most common, accounting for $40 \%$ of those diagnosed, while aneurysms of the descending thoracic aorta account for 35\%, with the remaining composed of aneurysms of the aortic arch (15\%) and the thoracoabdominal regions (10\%) [16]. TAAs occur most frequently in Caucasians, and they afflict men two to four times more frequently than women. The mean age at diagnosis is $60-70$ years of age [17]. The risk factors for developing aneurysms are similar to those for heart disease (atherosclerosis, hypertension, smoking, advanced age, and family history); however, the lack of aneurysm-specific symptoms often renders them un- noticed until the aorta ruptures, resulting in significant morbidity and mortality [3,16, 18-24]. While the most common etiology of TAA development is related to idiopathic aortic degeneration in patients with tricuspid aortic valves, other types of aortic aneurysm syndromes are associated with specific genetic conditions that carry a predisposition for TAA formation; these include possessing a congenital bicuspid aortic valve, Marfan syndrome, Loeys-Dietz syndrome, Ehlers-Danlos syndrome, and familial TAAs and dissections (TAADs) [3, 25]. When aortic dilatation is discovered, independent of the aneurysm etiology, aortic diameter is serially monitored over time using noninvasive imaging techniques. A high risk surgical procedure is often the only treatment option. There are currently no noninvasive interventional treatments available for these patients. Surgery is considered when: (1) the patient begins to experience specific symptoms; (2) the rate of aortic dilatation is determined to be greater than average $(1.0 \mathrm{~cm} /$ years); or (3) the aortic diameter reaches a critical size $(5.0-5.5 \mathrm{~cm}$ (ascending) or 6-6.5 $\mathrm{cm}$ (descending)) [26]; modified based on diagnosis, family history, or body surface area [27]. Thus, only when the risk of aortic rupture outweighs the risk of the surgical repair, is the patient treated. Although recent advancements, such as endovascular stent grafting and improvements in perioperative care have lessened the significant morbidity associated with open surgical repair, stenting may not permanently arrest aneurysm development, and continued disease progression may result in failure of the stent graft. Therefore, further diagnostic and therapeutic advancement is critical and especially relevant for those patients who have not yet reached surgical criteria.

\section{Vascular Remodeling and Aneurysm Formation}

Vascular remodeling collectively refers to the architectural alterations that occur in a vessel wall in response to hemodynamic changes or various forms of vascular injury. This adaptive process is induced to maintain the vessel lumen diameter and consistent blood flow under normal physiological conditions. Both clinical and basic research studies have characterized aneurysmal disease histologically based on the alterations that occur within the vascular ECM, primarily the pathological remodeling of collagen and elastin, the key structural proteins within the aortic vascular wall. This remodeling process is now understood to be driven by enhanced production of extracellular proteases and is accompanied by the loss 
of vascular smooth muscle cells (SMCs), together leading to pronounced medial atrophy $[2,5,28]$.

While the inciting pathological stimulus leading to aneurysm formation remains undefined, the development of experimental animal models that recapitulate many characteristics of human aneurysms has allowed hypothesis-directed investigation of specific proteolytic mechanisms driving aberrant vascular remodeling and aneurysm development [29-36]. Initial studies focused on the role of the matrix metalloproteinases (MMPs) in mediating ECM degradation during aneurysm formation $[2,3,5,35,37-41]$. The MMPs are a family of 27 unique extracellular proteases that are capable of degrading all aortic ECM constituents. MMP abundance and activity within the vascular wall is regulated by several mechanisms including transcriptional regulation, posttranslational activation and release, and the regulated production of endogenous tissue inhibitors (TIMPs). Within the normal aorta, a balance between these mechanisms is maintained in order to tightly control matrix degradation and matrix deposition. Within the aneurysmal aorta, however, this balance is disrupted by an overproduction of MMPs or an underproduction of TIMPs, favoring an enhanced proteolytic state and driving matrix degradation $[37,42,43]$. Thus, while the physiological remodeling process within the aortic vascular wall operates to maintain normal aortic function, pathological dysregulation can result in excessive degradation of critical ECM components, leading to loss of mechanical strength and integrity. This results in aortic dilatation, dissection, or rupture.

While the role of enhanced ECM proteolysis in TAA formation remains undisputed, the fundamental mechanisms regulating the balance between matrix deposition and degradation remain largely undiscovered. With the majority of previous studies focusing on the role of specific end effectors of aneurysm development, such as the MMPs, little information exists regarding the upstream signaling pathways that manage the pathological remodeling process. Hence, interest is shifting toward a mechanistic understanding of aneurysm formation and progression with a focus on identifying critical upstream regulators.

\section{TGF- $\beta$ Signaling}

TGF- $\beta$ is a soluble peptide growth factor that has been implicated in numerous divergent cellular processes including proliferation, angiogenesis, differentiation, apop- tosis, and wound healing [9,44-48], and is well described as a modifier of the structure and composition of the ECM. Best known for its role in stimulating collagen production and deposition, dysregulated TGF- $\beta$ signaling has been implicated in pathological fibrosis of the heart, lung, and liver [7, 49-51].

\section{Classical TGF- $\beta$ Signaling Pathway}

In the classical TGF- $\beta$ signaling pathway, upon release from sites of extracellular sequestration, TGF- $\beta$ (TGF$\beta 1$, TGF- $\beta 2$, TGF- $\beta 3$ ) dimerizes (forming predominantly homodimers) and binds to a heteromeric receptor complex consisting of two type I receptors and two type II receptors, both of which possess serine/threonine kinase activity (fig. 1) [52]. Upon ligand binding, the type II receptor recruits a type I receptor and activates it through a transphosphorylation event [53]. The activated type I receptor then phosphorylates a receptor-Smad (RSmad), a class of intracellular signaling intermediates named for their homologues in Caenorhabditis elegans (sma genes; SMAll, regulators of body size) and Drosophila [mad genes; mothers against decapentaplegic $(d p p)$ ]. The R-Smad then interacts with a co-Smad (Smad4), forming a complex that is shuttled into the nucleus where, upon interaction with transcriptional coregulators (activators or repressors), it forms a competent transcription complex capable of inducing or repressing numerous genes $[45,48,54,55]$. Accordingly, the classical TGF- $\beta$ signaling pathway involving the Smad-mediated signaling cascade has been characterized by signals that induce ECM deposition (e.g. collagen, elastin) [7, 56, 57] while also repressing ECM degradation (e.g. TIMP-1, TIMP-3) $[58,59]$.

\section{Regulation of TGF- $\beta$ Signaling}

TGF- $\beta$ was originally named for its ability to stimulate anchorage-independent growth in fibroblasts by inducing cellular transformation $[60,61]$. Not long afterwards, TGF- $\beta$ was also shown to function as a potent growth suppressor [62]. Attempts to dissect the TGF- $\beta$ pathway, separating its mitogenic responses from its growth suppression responses, initiated years of divergent results emphasizing the pleiotropic nature of TGF$\beta$ signaling. Since that time, the family of TGF- $\beta$ signaling receptors and intermediates has dramatically expanded, and now defines TGF- $\beta$ as one member of a superfamily of signaling components consisting of approximately 30 different ligands, 7 different type I receptors, 5 different type II receptors, and 8 different Smad proteins $[45,63]$. 


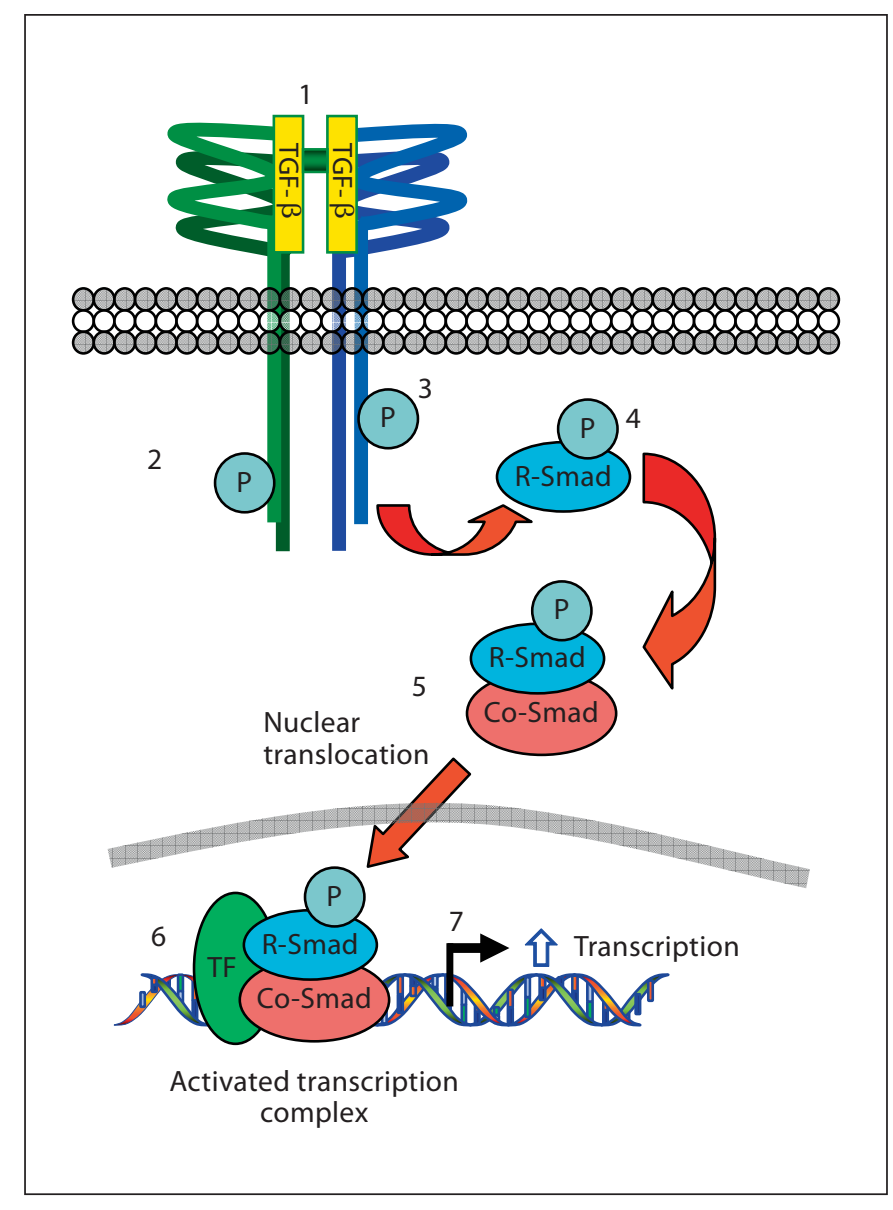

Fig. 1. Classical TGF- $\beta$ signaling pathway. The classical profibrotic TGF- $\beta$ signaling pathway is initiated upon binding of ligand to a homodimer of the type II TGF- $\beta$ receptor (TGF- $\beta$ RII) (1). The type II receptor is autophosphorylated (2); it then recruits and transphosphorylates a type I receptor (TGF- $\beta$ RI) (3). The activated type I receptor in turn phosphorylates and activates a receptor-Smad (R-Smad) (4). The R-Smad then binds the common co-Smad (5) and translocates to the nucleus (6). Once in the nucleus, it binds transcriptional cofactors and forms an activated transcriptional complex capable of inducing transcription of profibrotic genes (7).

TGF- $\beta$ signaling is regulated at multiple levels including mechanisms such as the extracellular regulation of ligand availability [64, 65], regulation at the transcriptional level by co-activators, co-repressors, and transcriptional terminators [66], and by multiple feedback and cross-talk mechanisms that terminate or re-direct the intracellular signal $[10,46,67]$. For example, the extracellular TGF- $\beta$ scavenging proteoglycan decorin binds TGF- $\beta$ in the ECM and limits its ability to interact with TGF- $\beta$ receptors. In a study by Coucke et al. [68], loss-of- function mutations were identified in the SLC2A10 gene that encodes the facilitative glucose transporter, GLUT10. Patients deficient in this transporter develop arterial tortuosity syndrome (ATS), characterized by a twisting/contortion of the large and medium-sized arteries (including the aorta), as well as aneurysms. Interestingly, the decorin gene is regulated in part by a glucose response element in its promoter. SMCs isolated from patients with ATS demonstrated severely reduced expression of decorin versus control cells [68]. In this example, the loss of decorin translated to an increase in the abundance of TGF- $\beta$ available for signaling within the ECM, which may be an underlying cause for ATS development. In another example, TGF- $\beta$ stimulation results in the induction of the inhibitory Smads (I-Smads; Smad6 and Smad7), which function to both mediate TGF- $\beta$ signaling cross-talk with other signaling pathways and attenuate the TGF$\beta$ signaling response [69]. Smad6 has been described to bind directly to the type-I TGF- $\beta$ receptor (TGF$\beta R I)$, thus preventing subsequent R-Smad phosphorylation [70]. This has been shown to interfere with the RSmad:co-Smad complex formation [71], attenuating nuclear translocation and the subsequent transcriptional activation mediated by the R-Smads. On the other hand, Smad7 interacts with the heteromeric TGF- $\beta$ receptor complex, and recruits the E3 ubiquitin-ligases Smurf1 and Smurf2 (Smad ubiquitination regulatory factor-1 and -2), targeting the receptors for degradation, thus terminating the signaling response $[67,72,73]$. The R-Smads and the co-Smad have also been shown to be regulated by TGF- $\beta$-induced Smurf activity $[48,74,75]$. Accordingly, these factors all work together to modify and direct the response to signals through this complex pathway (table 1).

Smad-Independent and Alternative TGF- $\beta$ Signaling

A growing body of evidence now supports the hypothesis that TGF- $\beta$ signaling can proceed by alternative mechanisms that bypass key mediators in the classical pathway (fig. 2) [47, 76-78]. For example, these responses include: (1) signals propagated directly by type II receptors without type I receptor involvement [79, 80]; (2) type I receptor signals in the absence of Smad activity [78, 81-84]; (3) R-Smad signaling to parallel pathways in the absence of co-Smad involvement [85-87], and (4) activation of R-Smads by other signaling mediators in response to TGF- $\beta$, but not as a result of direct interaction with TGF- $\beta$ receptors $[88,89]$. Thus, in addition to the classical signaling pathway, many of the downstream effects of TGF- $\beta$ may be mediated through alternative pathways 
Table 1. TGF- $\beta$ signaling pathway components and mediators

\begin{tabular}{|c|c|c|}
\hline Abbreviation & Name & Description/function \\
\hline \multicolumn{3}{|c|}{ TGF- $\beta$ pathway components } \\
\hline TGF- $\beta$ & transforming growth factor beta & $\begin{array}{l}\text { multifunctional growth factor that regulates ECM structure and composition; } \\
\text { TGF- } \beta-1,-2 \text {, and }-3\end{array}$ \\
\hline LAP & latency associated peptide & $\begin{array}{l}\text { TGF- } \beta \text { is synthesized as a prepropolypeptide that is cleaved into mature growth } \\
\text { factor and an LAP }\end{array}$ \\
\hline SLC & small latent complex & mature TGF- $\beta$ and the LAP self-associated to form the SLC \\
\hline LTBP & latent TGF- $\beta$ binding protein & binding proteins that sequester the TGF- $\beta$ SLC in the ECM \\
\hline LLC & large latent complex & LTBP binds the SLC to form the LLC \\
\hline TGF- $\beta$ RI & TGF- $\beta$ receptor 1 & $\begin{array}{l}\text { TGFBR1 gene; type I TGF- } \beta \text { receptor with serine/threonine kinase activity; } \\
\text { binds TGF- } \beta \text { RII and TGF- } \beta\end{array}$ \\
\hline TGF- $\beta$ RII & TGF- $\beta$ receptor 2 & $\begin{array}{l}\text { TGFBR } 2 \text { gene; type II TGF- } \beta \text { receptor with serine/threonine kinase activity; } \\
\text { binds TGF- } \beta \text { RI and TGF- } \beta\end{array}$ \\
\hline TGF- $\beta$ RIII & TGF- $\beta$ receptor 3 & $\begin{array}{l}\text { type III TGF- } \beta \text { receptor; accessory receptor that binds TGF- } \beta \text { and facilitates } \\
\text { interactions with type I and II receptors }\end{array}$ \\
\hline ALK-1 & activin receptor-like kinase- 1 & type I TGF- $\beta$ receptor that binds TGF- $\beta$ and activin \\
\hline Smad & $\begin{array}{l}\text { homologue to C. elegans SMA genes } \\
\text { (SMAll, body size regulators) and } \\
\text { drosophila MAD (mothers against } \\
\text { decapentaplegic) genes }\end{array}$ & $\begin{array}{l}\text { TGF- } \beta \text { signaling intermediates that translate receptor signals into transcriptional } \\
\text { responses }\end{array}$ \\
\hline R-Smads & receptor-Smads & $\begin{array}{l}\text { phosphorylated by direct interaction with TGF- } \beta \text { receptor complex } \\
(\text { Smad1, } 2,3,5,8)\end{array}$ \\
\hline $\begin{array}{l}\text { Phospho- } \\
\text { Smad }\end{array}$ & phosphorylated Smad & $\begin{array}{l}\text { phosphorylated R-Smad, phosphorylation regulates interactions with co-Smad } \\
\text { and transcriptional co-regulators. }\end{array}$ \\
\hline Co-Smad & co-regulatory Smad & $\begin{array}{l}\text { Smad4, binds phosphorylated R-Smad and translocates to the nucleus to regulate } \\
\text { transcription }\end{array}$ \\
\hline$\underline{\text { I-Smad }}$ & inhibitory Smad & Smad6, Smad7; assist in the regulation/termination of Smad-mediated signaling \\
\hline SARA & Smad anchor for receptor activation & $\begin{array}{l}\text { facilitates segregation of TGF- } \beta \text { receptor complexes into the clathrin-mediated } \\
\text { endocytic pathway for recycling, and facilitates interactions with Smad } 2\end{array}$ \\
\hline \multicolumn{3}{|c|}{ TGF- $\beta$-induced signaling mediators } \\
\hline COL1A1 & type 1 collagen $\alpha_{1}$-chain & \multirow{3}{*}{ type I and type III collagen; major aortic fibrillar collagens induced by TGF- $\beta$} \\
\hline COL1A2 & type 1 collagen $\alpha_{2}$-chain & \\
\hline COL3A1 & type 3 collagen $\alpha_{1}$-chain & \\
\hline CTGF & connective tissue growth factor & $\begin{array}{l}\text { TGF- } \beta \text {-induced growth factor that induces fibroblast proliferation, migration, } \\
\text { and ECM protein production }\end{array}$ \\
\hline PAI-1 & plasminogen activator inhibitor-1 & inhibits the activation of $\mathrm{uPA}$ and $\mathrm{tPA}$ \\
\hline$\underline{\mathrm{uPA}}$ & urokinase-type plasminogen activator & \multirow{2}{*}{ plasminogen activators that are known to activate several MMP species } \\
\hline $\mathrm{tPA}$ & tissue-type plasminogen activator & \\
\hline Smurf & Smad ubiquitination regulatory factor & $\begin{array}{l}\text { E3 ubiquitin ligase induced by TGF- } \beta \text {; regulates TGF- } \beta \text { signaling by targeting } \\
\text { TGF- } \beta \text { receptors, R-Smads, and co-Smads for proteasomal degradation }\end{array}$ \\
\hline$\underline{E R K 1 / 2}$ & extracellular regulated kinase $1 / 2$ & \multirow{4}{*}{$\begin{array}{l}\text { other signaling intermediates that are activated by TGF- } \beta \text {, primarily through } \\
\text { alternate and non-Smad-mediated signaling pathways }\end{array}$} \\
\hline p38MAPK & p38 mitogen-activated protein kinase & \\
\hline $\mathrm{PI} 3 \mathrm{~K}$ & phosphatidylinositol-3-kinase & \\
\hline $\mathrm{PKC}$ & protein kinase $\mathrm{C}$ & \\
\hline
\end{tabular}

that do not involve Smad-mediated transcriptional activity.

Through the appreciation of these combinatorial receptor interactions, multiple regulatory mechanisms, and alternative signaling pathways, we are slowly gaining an understanding of the regulatory events that are responsible for the complexity and diversity of TGF- $\beta$ signaling outcomes. 


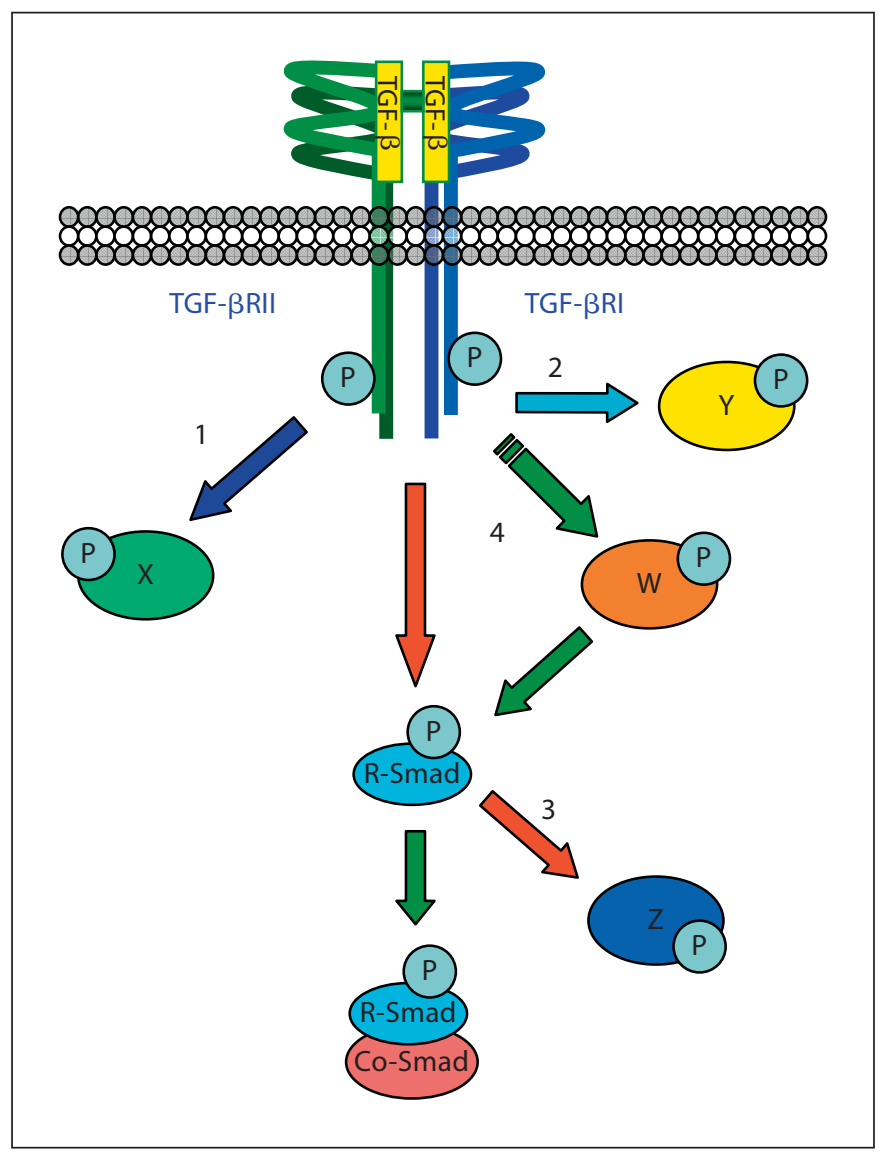

Fig. 2. Alternative TGF- $\beta$ signaling mechanisms. Signaling directly mediated by the type II receptor (TGF- $\beta$ RII) without type I receptor (TGF- $\beta$ RI) function (1), type I receptor signaling independent of Smad function (2), R-Smad signaling independent of co-Smad interaction (3), and R-Smad activation in response to TGF- $\beta$ but in the absence of direct TGF- $\beta$ receptor interaction (4). Adapted from reviews by Derynck and Zhang [76] and Moustakas and Heldin [47].

\section{TGF- $\beta$ Effects on the ECM}

Just as TGF- $\beta$ was identified as a bifunctional regulator of cell growth, TGF- $\beta$ signaling has been attributed to many other opposing and disparate cellular functions. As such, TGF- $\beta$ has been implicated not only in matrix deposition, but also in matrix degradation, positioning it as a critical mediator of the structure and composition of the ECM.

Early studies examining the biological effects of TGF$\beta$ on both primary and cultured cells demonstrated that TGF- $\beta$ treatment could enhance the production of type I and type III collagen [90-93]. Subsequent studies revealed that collagen production was a result of enhanced

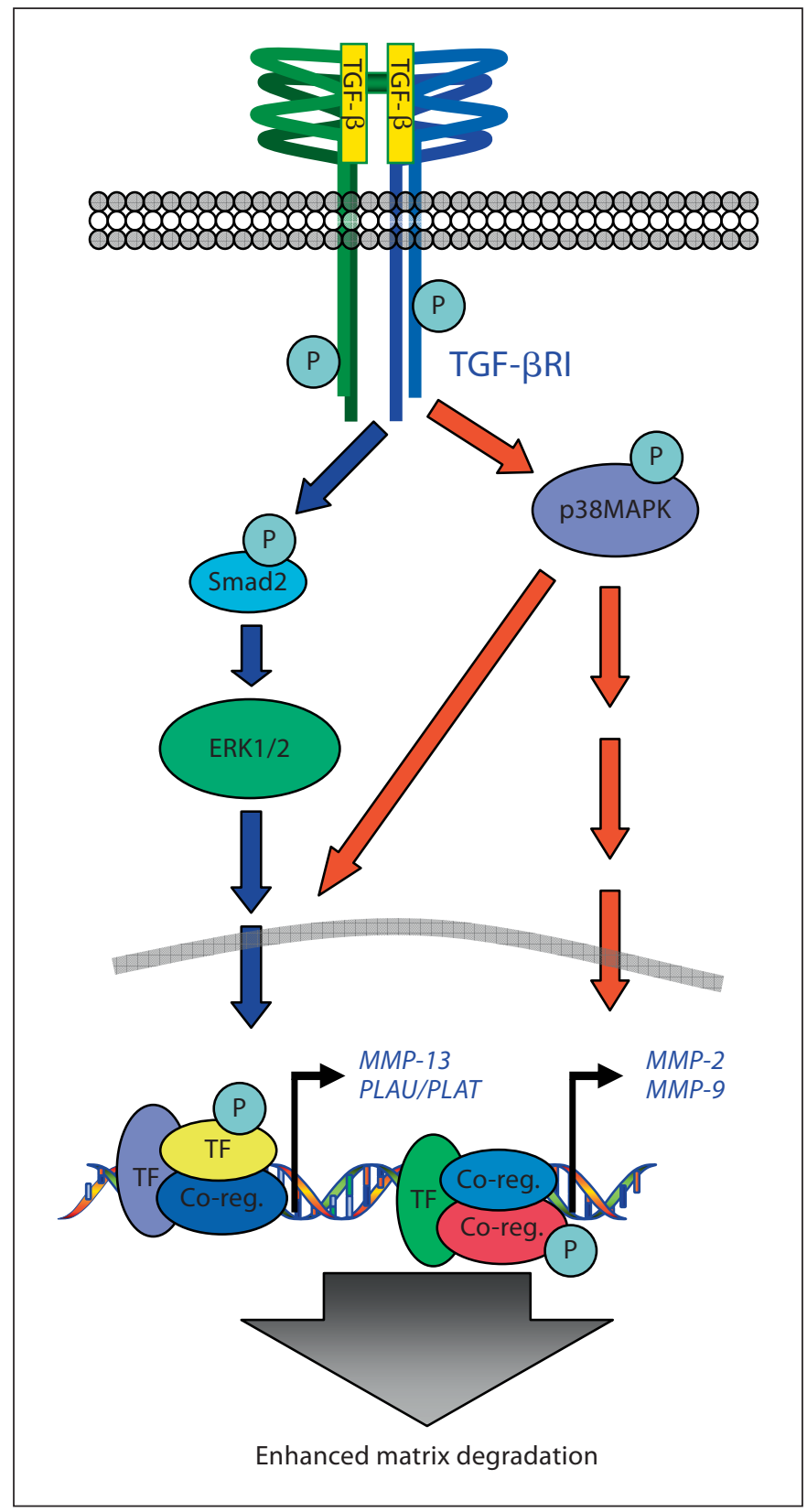

Fig. 3. Mechanisms for TGF- $\beta$-induced matrix degradation. TGF- $\beta$ stimulates matrix degradation primarily through nonSmad-mediated pathways that may also involve Smad activation, and results in the increased expression of extracellular protease genes. PLAU/PLAT = Urokinase-type plasminogen activator/tissue-type plasminogen activator.

collagen gene expression [94-96]. These studies defined a role for TGF- $\beta$ in normal fibrogenesis. It was then postulated that the TGF- $\beta$ signaling pathway may serve as a significant therapeutic target for the treatment of patho- 
logical fibrosis. Indeed, in a study by Smith et al. [97], delivery of a recombinant soluble type II TGF- $\beta$ receptor prevented adventitial fibrosis and collagen deposition in a rat carotid balloon-injury model. In similar fashion, cells exposed to the proteoglycan decorin, which binds and sequesters TGF- $\beta$, dose-dependently inhibited collagen synthesis in isolated scar-derived fibroblasts [98]. As the TGF- $\beta$ signaling pathway has become more defined, a clear role for TGF- $\beta$ in collagen production and pathological fibrosis has now been well established [99, 100].

In addition to stimulating the production of matrix proteins, TGF- $\beta$ has also been shown to affect matrix deposition through other modalities. For example, other profibrotic genes are induced in response to TGF- $\beta$, including connective tissue growth factor (CTGF) which acts on fibroblasts to induce proliferation, migration, adhesion, and ECM protein production [101]. Furthermore, tropoelastin mRNA stability was increased in fibroblasts treated with TGF- $\beta$ [56]. This response was shown to be dependent on Smad-mediated signaling, but also required protein kinase $\mathrm{C}$ and $\mathrm{p} 38$ mitogen activated protein kinase (p38MAPK) activity [57]. As well, TGF- $\beta$ has been shown to actively inhibit matrix degradation by at least two independent mechanisms. First, it was demonstrated that TGF- $\beta$ could induce endogenous protease inhibitors. The expression of plasminogen activator inhibitor-1 (PAI-1), an endogenous inhibitor of the plasminogen activators (urokinase-type plasminogen activator and tissue-type plasminogen activator), which are well known upstream activators of the MMPs [102], was found to be induced in response to TGF- $\beta$ treatment $[12,103]$. Similarly, TGF- $\beta$ was shown to induce several TIMP species which function as direct inhibitors of MMP activity. In fibrosarcoma cells, Kwak et al. [58] demonstrated TGF- $\beta$-mediated induction of TIMP-1 through an extracellular regulated kinase 1 and 2 (ERK1/2)-dependent pathway. Likewise, work by Garciá-Alvarez et al. [59] established that TGF- $\beta 1$ could induce Timp-3 gene expression and protein production in primary lung fibroblasts. Second, several of the MMP species (-1, -7 , and -13) have promoter binding regions (termed TGF- $\beta$ inhibitory elements) for transcription factors that mediate the direct repression of $M M P$ gene expression [104, 105]. Additionally, Kerr et al. [106] also demonstrated TGF- $\beta$-induced repression of $M M P-3$ mediated in part by c-fos-containing protein complexes. Furthermore, Edwards et al. [107] demonstrated that the co-treatment of fibroblasts with TGF- $\beta 1$ could mediate the repression of growth-factorinduced collagenase expression while synergistically en-
Table 2. Outcomes of classical TGF- $\beta$ signaling affecting matrix deposition

\begin{tabular}{|c|c|c|}
\hline Mediator & Outcome (genes involved) & Ref. \\
\hline \multicolumn{3}{|c|}{ Effects on matrix synthesis } \\
\hline Collagen & $\begin{array}{l}\text { enhanced collagen expression, synthesis, and } \\
\text { deposition (COL1A1, COL1A2, COL } 3 A 1)\end{array}$ & $90-93$ \\
\hline CTGF & $\begin{array}{l}\text { increased connective tissue growth factor } \\
\text { expression (CTGF) }\end{array}$ & 101 \\
\hline Elastin & $\begin{array}{l}\text { tropoelastin mRNA half-life is stabilized, } \\
\text { increasing elastin expression (ELN) }\end{array}$ & 56,57 \\
\hline \multicolumn{3}{|c|}{ Effects on matrix degradation } \\
\hline PAI-1 & $\begin{array}{l}\text { increased PAI- } 1 \text { expression; inhibits } \\
\text { activation of uPA and tPA, activators of } \\
\text { MMPs (PLAU and PLAT, respectively) }\end{array}$ & 12,103 \\
\hline TIMP & $\begin{array}{l}\text { induction of TIMP- } 1,-3 \text { expression, } \\
\text { direct inhibitors of MMP activity } \\
(T I M P-1, T I M P-3)\end{array}$ & 58,59 \\
\hline MMPs & $\begin{array}{l}\text { direct repression of MMP expression medi- } \\
\text { ated by TGF- } \beta \text { inhibitory elements (TIE) } \\
\text { within the MMP promoter (MMP - } 1,-7 \text {, } \\
-13) ; M M P-3 \text { repression by c-fos complexes }\end{array}$ & $104-106$ \\
\hline
\end{tabular}

hancing TIMP expression. Hence, TGF- $\beta$ can drive matrix deposition by inhibiting matrix-degrading enzymes (either directly or by blocking activation) as well as by repressing their transcription. In terms of the functional consequences of TGF- $\beta$-mediated inhibition of matrix degradation, it was suggested that overexpression of TGF$\beta$ may therefore be able to stabilize the degenerative ECM remodeling observed during aneurysm development. Indeed, in a study by Dai et al. [108], virus-mediated overexpression of TGF- $\beta 1$ in rat abdominal aortic aneurysms increased endogenous TGF- $\beta 1$ levels, stabilized aortic dilatation, and attenuated vascular degeneration.

Taken together, these studies suggest that the multiple outcomes of TGF- $\beta$ signaling, specifically the production of matrix proteins along with the repression or inhibition of matrix degrading enzymes, work in concert to regulate matrix deposition (table 2).

In stark contrast to these results, TGF- $\beta$ signaling has also been implicated in pathways directly leading to enhanced ECM degradation and the production of various MMP species. In human skin fibroblast cultures, TGF- $\beta$ treatment induced the production of plasminogen activator [12]. In breast cancer cells, TGF- $\beta$ treatment rapidly activated $\mathrm{p} 38 \mathrm{MAPK}$, leading to the production and release of MMP-2 and MMP-9 [11]. In rat osteoblast cultures, TGF- $\beta$ was shown to stimulate $M m p-13$ expres- 
sion, which was dependent on Smad2, p38MAPK, and ERK1/2 signaling [14]. Furthermore, Safina et al. [13] revealed that breast cancer cell invasion and tumor angiogenesis were dependent on signaling through the type I TGF- $\beta$ receptor, and resulted in MMP- 9 production. Interruption of the TGF- $\beta$ signaling pathway by overexpressing a kinase-deficient type I receptor attenuated both angiogenesis and $M M P-9$ expression. Thus, these data suggest that non-Smad-mediated TGF- $\beta$ signaling pathways dependent on TGF- $\beta$ RI, and often in combination with Smad-mediated signaling, can stimulate the proteolytic destruction of the vascular ECM (fig. 3).

\section{TGF- $\beta$ and Vascular Pathology}

It is becoming apparent, as the above data illustrate, that TGF- $\beta$ signaling can regulate the production of critical vascular matrix proteins as well as matrix-degrading enzymes, and suggests that perturbations in the TGF- $\beta$ signaling pathway may be detrimental to normal vascular function and architecture. Accordingly, alterations in normal TGF- $\beta$ signaling have been implicated in the pathophysiology of several vascular disorders including atherosclerosis $[3,109-112]$, primary pulmonary hypertension [113-116], and a host of aortic aneurysm syndromes which are placed in context below.

\section{Hereditary Hemorrhagic Telangiectasia}

In addition to the type I and type II TGF- $\beta$ receptors, the type III auxiliary receptors (endoglin, betaglycan; TGF- $\beta$ RIII) bind TGF- $\beta$ and function to sequester it in the ECM, thereby regulating ligand availability and its interaction with the type I and II receptors [117]. Recently, TGF- $\beta$ RIII was shown to directly influence TGF- $\beta$-mediated growth inhibition by enhancing both Smad3- and p38MAPK-dependent signaling [118]. Interestingly, mutations in endoglin were directly linked to the development of hereditary hemorrhagic telangiectasia (HHT1, OMIM \#187300), a disorder that results in vascular dysplasia and arteriovenous malformations. Similarly, mutations in the $A C V R L 1$ [activin A receptor, type II-like 1 or activin receptor-like kinase-1 (ALK-1)] gene, a type I TGF$\beta$ receptor that binds TGF- $\beta$ /activin and has enhanced expression in highly vascularized tissues and endothelial cells $[119,120]$, has been linked to the development of HHT2 (OMIM \#600376) [119]. Moreover, the targeted deletion of Acvrl1 (the Alk-1 gene in mice) has been associated with enhanced production of angiogenic factors and plasminogen activators; both of which serve to stimulate vascular remodeling through the induction and activation of extracellular proteases [121]. Interestingly, in the Acvrl1 deficient mice, dilatation of the yolk-sac vasculature was observed at day E9.5, prior to embryonic lethality at day E11.5 [121]. Thus it was postulated that ALK-1 signaling negatively regulates angiogenesis and vascular remodeling. It is interesting to speculate that interruption of ALK-1-mediated signaling may induce angiogenic factors (i.e. specific MMPs) that contribute to the degradation of the vascular ECM and aortic dilatation. Indeed enhanced angiogenesis has been implicated in the development of abdominal aortic aneurysms [122-124].

\section{Marfan Syndrome}

Marfan syndrome (MFS; OMIM \#154700) is an inherited connective tissue disorder characterized by cardiovascular, skeletal, and ocular abnormalities that display an autosomal dominant inheritance pattern with variable penetrance [125]. The primary gene defect lies on chromosome 15q21.1 within the coding sequence for the fibrillin1 gene (FBN1); a principal component of the 10 - to $12-\mathrm{nm}$ microfibrils that form the scaffold for elastin assembly within the ECM $[125,126]$. The primary cause of morbidity and mortality in MFS patients relates to the common development of cardiovascular complications including annulo-aortic ectasia and dilatation of the aortic root, thus leading to the formation of ascending aneurysms and dissections $[127,128]$. These lesions develop secondary to pathological remodeling events that occur within the medial and adventitial vascular ECM consisting of SMC loss, elastin breakdown, and accumulation of cyst-like structures containing mucopolysaccharide [125].

Fibrillin-1 (and the closely related fibrillin-2) is a 350$\mathrm{kDa}$ glycoprotein comprised of tandem repeats of an epidermal growth factor (EGF)-like motif; most of which contain a calcium-binding sequence (cbEGF) [129]. Fibrillin monomers self-assemble into macroaggregates that form the basic structure on which mature elastin fibers are synthesized from tropoelastin subunits. The cbEGF modules function to sequester extracellular calcium to protect against ECM proteolysis, mediate interactions between fibrillin monomers and other cellular components such as integrin $\alpha v \beta 3$, and stabilize the structure of the microfibrils to favor lateral packing [130, 131]. Thus, mutations in fibrillin-1 within the aorta result in weakened and disordered elastic fibers, as well as disruption of the microfibril network connecting the elastic lamellae to the adjacent interstitial cells $[132,133]$.

In addition to directing elastogenesis and providing structural integrity to the elastic lamellae, fibrillin-rich 
microfibrils have also been shown to sequester TGF- $\beta$ within the ECM. TGF- $\beta$ is synthesized as a prepropolypeptide that is cleaved in a post-Golgi compartment to yield the mature growth factor and a latency-associated peptide (LAP). Homodimers of mature TGF- $\beta$ and LAP form a tight biologically inactive complex termed the 'small latent complex' (SLC) [134]. The SLC is covalently bound to a latency-associated TGF- $\beta$ binding protein (LTBP) through disulfide bonds that form between cysteine residues in the LAP and a cysteine-rich motif in LTBP $[131,135,136]$. This large latent complex is secreted from the cell and functions to target TGF- $\beta$ to the ECM, and specifically to fibrillin microfibrils, which have been shown to directly bind LTBPs $[137,138]$. TGF- $\beta$ can be made available for signaling upon release from the LAP through a number of activation mechanisms including: proteolysis of latent complexes, thrombospondin-1 competition with SLC for LTBP binding, integrin binding to embedded RGD peptide sequences within the LTBP (the central peptide sequence that binds $\alpha v \beta 3$ integrin), or exposure to acidic/oxidative stress $[135,136,139]$. Thus, it was suggested that abnormalities in FBN-1 function such as those observed in MFS may lead to impaired sequestration of latent TGF- $\beta$ complexes, thereby making more available for activation, and potentially leading to enhanced TGF- $\beta$ signaling [125]. This hypothesis was confirmed by two key studies. First, Neptune et al. [140] demonstrated that lung abnormalities, evident in the immediate postnatal period in mice deficient in fibrillin-1 $\left(F b n 1^{m g \Delta / m g} \Delta\right)$, were related to enhanced TGF- $\beta$ activation and signaling, and that the perinatal administration of a TGF- $\beta$-neutralizing antibody could rescue the defect in alveolar septation. Second, in mice carrying a hypomorphic allele of the Fbn-1 gene (Fbn1C1039G/+), effectively recapitulating a mouse model of Marfan syndrome, Habashi et al. [141] observed that treatment with a TGF$\beta$-neutralizing antibody or the angiotensin II type I receptor antagonist Losartan was sufficient to attenuate spontaneous aortic root dilatation, elastic fiber fragmentation and Smad 2 activation. Together, these studies suggest that sequestration of TGF- $\beta$ in the ECM is critical to its regulated activation, and mutations that functionally impair its sequestration likely contribute to the pathogenesis of MFS, and in particular the pathogenesis of ascending TAA.

\section{MFS Type 2}

The diagnosis of MFS has been based on a defined set of clinical criteria [142-144]. Interestingly, approximately $10 \%$ of patients classified as having MFS failed to show a defect in the FBN1 gene, suggesting that a second genetic locus is linked to MFS [145-147]. Originally reported in a French family by Boileau et al. [148], this syndrome was clinically very similar to classic MFS but with no ocular involvement. Subsequent linkage analysis by Collod et al. [145] mapped the defect to a locus on chromosome 3p25-24.2 and designated the syndrome 'Marfan syndrome type 2' (MFS2; OMIM \#154705). When a Japanese individual with MFS was found to have a chromosome break at $3 \mathrm{p} 24.1$, within the gene encoding the type II TGF- $\beta$ receptor (TGFBR2), Mizuguchi et al. [149] hypothesized that the TGFBR2 gene may be linked with the MFS2 locus. Subsequent analysis revealed a mutation ( $1524 \mathrm{G}$ to $\mathrm{A})$ which resulted in a synonymous amino acid substitution (Q508Q), but disrupted an RNA splice site, leading to early termination and truncation of the TGF- $\beta$ RII protein [149]. Three other mutations in two unrelated families were also identified, all of which fell within the kinase domain of TGF- $\beta$ RII and led to the loss of functional TGF- $\beta$ signaling. Thus, the MFS phenotype can be caused by mutations in both $F B N 1$ and TGFBR2, and in both cases, the alterations in the TGF- $\beta$ signaling may contribute to the underlying cause of aneurysm formation. While enhanced TGF- $\beta$ signaling was associated with dilatation of the ascending aorta in a mouse model of MFS [141], the loss of TGF- $\beta$ signaling appeared to be linked to aneurysm formation in MFS2 [149].

\section{Familial TAAs and Dissections}

In addition to the classified aneurysm syndromes that are directly associated with specific gene defects, such as MFS, as described above, an expanding collection of studies have identified TAAs and dissections that are not clearly associated with an identifiable syndrome. Of these individuals, approximately $20 \%$ display a genetic predisposition that was inherited in an autosomal dominant manner with decreased penetrance and variable expression [150-152]. These nonsyndromic cases have collectively been referred to as familial TAAs and dissections (TAADs). Currently, six causal genetic loci have been identified and linked to TAAD: 11q23.3-q24 (AAT1; OMIM \#607086), 5q13-q14 (AAT2; OMIM \#607087), 3p24-25 (AAT3; OMIM \#608967), 16p13.13-p13.12 (AAT4; OMIM \#132900), 9q33-q34 (AAT5; OMIM \#610380), and 10q22-q24 (ACTA2; OMIM \#102620). Candidate genes mapping to these intervals have revealed several interesting mutations in genes encoding the smooth muscle myosin heavy chain ( $\beta$ ) (Myh11; AAT4) [153], $\alpha$-smooth muscle actin ( $\alpha 2$; ACTA2) [154], and in 
both TGF- $\beta$ receptors (TGFBR1, AAT5 and TGFBR2, AAT3) [155-157].

In a study by Pannu et al. [158], four unrelated families were found to have mutations in the TGFBR2 gene, but tested negative for any signs of MFS. In all four cases, structural analysis revealed mutations of the arginine residue at position 460; a key residue that was found within the highly conserved serine/threonine kinase domain and was predicted to disrupt receptor function [158]. In similar fashion, Matyas et al. [156] screened 70 individuals that displayed phenotypes related to MFS, but tested negative for mutations in FBN-1. Of these individuals, 9 were identified to have TGFBR1 sequence variants that segregated within family groups and with TAAD disease, suggesting a causative link. Thus taken together, the loss of signaling through TGF- $\beta$ receptors I and II may therefore be associated with the development of familial TAAD.

\section{Loeys-Dietz Syndrome}

Work by Loeys et al. [159] as well as other laboratories [160] has recently described another condition that presented with symptoms similar to MFS, but included a greater cardiovascular risk. This disorder was designated Loeys-Dietz syndrome (LDS, OMIM \#609192), and was characterized by the enhanced development of aortic aneurysms and dissections that occur at a younger age and smaller aortic diameter [159]. Heterozygous mutations were identified in both TGFBR1 and TGFBR2 genes, thus it was initially suggested that the loss of TGF- $\beta$ signaling may be the underlying cause of LDS. Interestingly, aortic tissues derived from affected patients showed elevated protein levels of collagen and CTGF; both of which are well-described indicators of active TGF- $\beta$ signaling [159]. Even more compelling, the tissues displayed enhanced nuclear translocation of phospho-Smad2, suggesting that there was an enhancement, not a repression, of TGF- $\beta$ signaling in these aortic specimens. Upon culturing fibroblasts from affected individuals it was hypothesized that, although the mutant TGF- $\beta$ receptors were unable to transmit signals, the wild-type receptor (also expressed in a heterozygous individual) retained its acute responsiveness to TGF- $\beta$, and in fact displayed elevated activity [159]. Thus, consistent with the observations from the MFS patient studies and the MFS mouse model, the authors concluded that an enhancement of TGF- $\beta$ signaling drove aortic dilatation and aneurysm formation in patients with LDS.
Ehlers-Danlos Syndrome Type IV

Ehlers-Danlos syndrome type IV (EDS, OMIM \#130050), also known as vascular type EDS, primarily affects the skin and large arteries and can lead to medial degenerative disease of the aorta resulting in acute dissection. The original cause was linked to a $3.3-\mathrm{kb}$ DNA deletion in one allele of the type III procollagen gene (COL3A1), which results in a truncated procollagen monomer that has decreased thermal stability, cannot be proteolytically processed, and cannot be efficiently secreted [161]. The end effect on the large arteries (including the aorta) is a diminished collagen network, with a low intimal-medial thickness, increased wall stress, and a propensity for acute dissection and rupture [162]. Diagnosis of EDS type IV can be difficult since there is significant phenotypic overlap with patients presenting with LDS. Loeys et al. [151], while characterizing 52 LDS-affected families for mutations in TGFBR1 and TGFBR2 genes also assessed a cohort of EDS type IV patients that lacked the COL3A1 gene mutations and the craniofacial features of the typical LDS patient. Interestingly, 12 EDS type IV probands were identified that possessed TGFBR 1 or TGFBR2 mutations, suggesting a possible re-classification of this group as LDS type 2 . Hence, in addition to COL3A1 mutations, this predisposition to acute aortic dissection may also be driven by mutations in TGF- $\beta$ receptors, like the LDS patients with TGF- $\beta$ receptor mutations that display signs of elevated TGF- $\beta$ signaling [159]. It is interesting to speculate whether EDS type IV patients with COL3A1 mutations show enhanced TGF- $\beta$ signaling in an effort to compensate for the loss of type III collagen within the aorta. In either case, within the aorta, the importance of proper regulation of the TGF- $\beta$ signaling pathway and its downstream transcriptional targets is further emphasized.

\section{Proposed Mechanisms of TGF- $\beta$-Mediated Aneurysm Formation}

As put forward by the pathophysiological studies above, alterations in TGF- $\beta$ signaling may therefore be an underlying factor contributing to the development of TAAs. While the majority of studies demonstrated that loss-of-function mutations within the kinase domain of the type I or type II TGF- $\beta$ receptors were associated with TAA formation, the predominant emerging theory suggests that overstimulation of the TGF- $\beta$ signaling is associated with enhanced proteolysis of the vascular ECM. Accordingly, based on additional in vitro and in vivo 
studies, some potential mechanisms have emerged that may help to explain (1) how the loss of TGF- $\beta$ RII kinase activity can result in enhanced TGF- $\beta$ signaling, and (2) how stimulation of the TGF- $\beta$ signaling pathway, generally believed to be profibrotic, can drive matrix degradation during aneurysm development.

\section{Enhanced Signaling by Mutant Receptors}

In the study by Loeys et al. [159], LDS was associated with deficient TGF- $\beta$ RII receptor kinase function, yet paradoxically displayed evidence of enhanced TGF- $\beta$ signaling; including enhanced expression of PAI-1, collagen, and CTGF, as well as nuclear localization of phospho-Smad2. Thus, other aneurysm syndromes associated with TGFBR2 mutations may also be a result of overstimulation of the TGF- $\beta$ pathway. While it is difficult to reconcile how kinase-deficient TGF- $\beta$ receptors could result in enhanced TGF- $\beta$ signal transmission, there are several potential mechanisms that could account for these observations.

First, Denton and coworkers developed a transgenic mouse that expressed a fibroblast-restricted kinase-deficient TGF- $\beta$ RII under control of the COL1A2 promoter [163]. Based on in vitro results characterizing the overexpression of the mutant receptor, the authors had predicted that the transgene would have a dominant-negative effect in mice, thus resulting in the fibroblast-specific suppression of TGF- $\beta$ signaling. Surprisingly, they observed the opposite: the mice developed dermal and pulmonary fibrosis, and isolated transgenic fibroblasts displayed hallmarks of enhanced TGF- $\beta$ signaling. To explain these paradoxical results, the authors suggested that the dominant-negative TGF- $\beta$ receptor may enhance TGF- $\beta$ signaling in functional TGF- $\beta$ receptor complexes by facilitating ligand interactions with the functional receptors, similar to the type III TGF- $\beta$ receptors endoglin and betaglycan [164]. They also suggested that the presence of the mutant TGF- $\beta$ RII may modify the orientation of wild-type receptors in a manner that would more easily facilitate signaling. Thus, the enhanced TGF- $\beta$ signaling observed in aneurysm syndromes associated with heterozygous TGF- $\beta$ receptor mutations may be a result of mutant receptors functioning as accessory receptors that facilitate ligand binding.

Secondly, kinase-deficient receptors may enhance TGF- $\beta$ signaling by altering the cellular dynamics of receptor stability. It is well known that endocytosis of cell surface receptors is an important regulatory step in the transduction of intracellular signals. Di Guglielmo et al. [165] described internalization of TGF- $\beta$ receptors by both clathrin-mediated and caveolin-mediated endocytic pathways. Interestingly, segregation into the clathrinmediated pathway sustained receptor recycling and propagated receptor signaling, whereas segregation into the caveolin-mediated pathway led to receptor degradation and termination of TGF- $\beta$ signaling. This process is regulated by receptor interactions with accessory proteins that direct the fate of TGF- $\beta$ signaling. For example, Di Guglielmo et al. [165] showed that the Smad anchor for receptor activation (SARA) interacted with TGF- $\beta$ RII at the plasma membrane, facilitating segregation into the clathrin-dependent endocytic pathway, as well as facilitating the interaction of the receptor complex with Smad2. This resulted in signal propagation and eventual receptor recycling to the plasma membrane. Alternatively, it was shown that Smad7 interacted with the heteromeric TGF- $\beta$ receptor complex (requiring both receptors for efficient interaction), facilitating segregation into the caveolin-mediated endocytic pathway, and recruiting the E3 ubiquitin ligases Smurf1 and Smurf2 $[165,166]$. This resulted in the ubiquitin-mediated proteasomal degradation of TGF- $\beta$ receptors, and thus the attenuation of TGF- $\beta$ signaling. Hence, it is possible that the TGFBR 2 mutations observed in the above aneurysm syndromes may facilitate interactions with SARA or diminish association with Smad7, preventing segregation into the caveolin-mediated pathway, subsequently resulting in the prolonged activation of TGF- $\beta$ signal transmission (fig. 4).

Lastly, it is also possible that TGF- $\beta$ receptor complexes that incorporate kinase-deficient receptors, while unable to signal directly, retain the ability to form functional signaling platforms and mediate interactions between other critical intracellular signaling components (fig. 5). For example, Runyan and coworkers showed that stimulation of human mesangial cells with TGF- $\beta$ resulted in the induction collagen gene expression (COL1A2) that was dependent upon phosphoinositide 3-kinase (PI3K) activity [88]. Using a pharmacological inhibitor of PI3K (LY294002) in combination with phosphorylation site mutants of Smad3, they demonstrated that PI3K catalyzed collagen gene expression by directly phosphorylating Smad3 at residues other than those within the TGF- $\beta$ RI target site. Thus, the binding of TGF- $\beta$ induced a receptor signaling complex which included at least PI3K and Smad3, and led to Smad3-mediated collagen gene expression that was not dependent on phosphorylation by TGF- $\beta$ RI. Therefore, TGF- $\beta$ RII mutants that retain the ability to bind TGF- $\beta$ may induce signaling through alternate pathways that are independent of receptor kinase activity. 


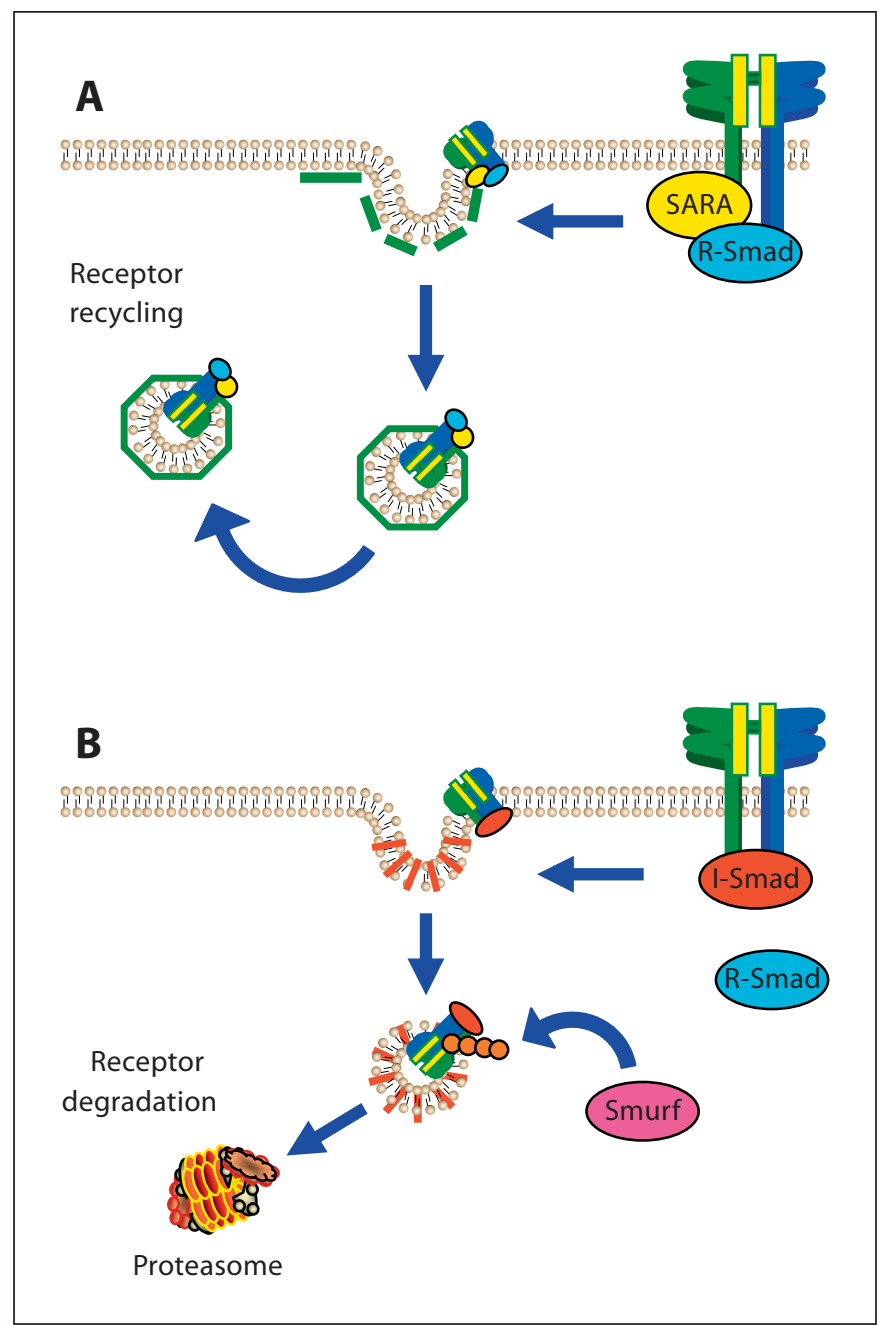

Fig. 4. Potential mechanism for enhancement TGF- $\beta$ signaling in the presence of receptor mutations. The endocytosis and subsequent recycling or degradation of TGF- $\beta$ receptors is an important mechanism for regulating TGF- $\beta$ signaling. There are two independent endocytic pathways, regulated by accessory protein interactions that exist to regulate TGF- $\beta$ signaling. The TGF$\beta$ RII mutations identified in several aneurysm syndromes may contribute to the enhanced TGF- $\beta$ signaling by facilitating interactions with SARA, or by diminishing association with Smad7, favoring receptor recycling and resulting in prolonged activation of TGF- $\beta$ signals. A Clathrin-mediated pathway leading to receptor recycling. B Caveolin-mediated pathway leading to proteasomal degradation of TGF- $\beta$ receptors.

\section{TGF- $\beta$-Induced Matrix Degradation}

As detailed above, elevated TGF- $\beta$ levels and/or evidence of functional TGF- $\beta$ signaling have been associated with TAA development. Furthermore, it is becoming clear that TGF- $\beta$ not only functions to induce matrix

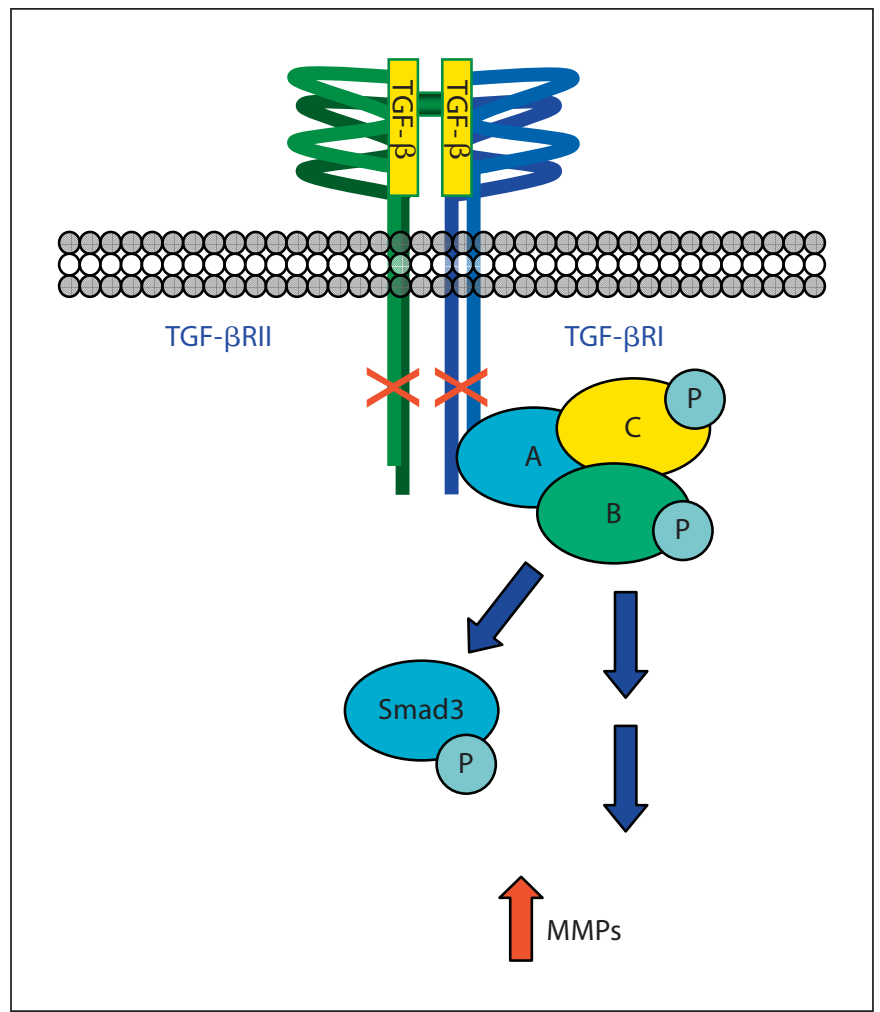

Fig. 5. Potential mechanism for enhancement of TGF- $\beta$ signaling in the presence of nonfunctional receptors. Ligand-induced receptor signaling complexes that are unable to transmit signals because of mutations within the receptor kinase domain (TGF$\beta R I I / T G F-\beta R I /$ both), may still function by seeding active signaling platforms that localize other signaling components capable of inducing downstream signaling events that contribute to aneurysm development.

deposition, but has also been implicated in regulating matrix degradation, in part due to its ability to induce matrix-degrading enzymes such as the MMPs (fig. 3). In fact, the majority of studies demonstrating TGF- $\beta$-dependent protease production implicate activated TGF$\beta R I$ and MAP kinases ERK1/2 and p38 [11-14]. Hence, TGF- $\beta$-induced matrix degradation may be driven by non-Smad-mediated pathways, either alone or in combination with Smad-mediated signaling $[45,167,168]$. Whereas hypotheses explaining elevated TGF- $\beta$ tissues levels have been proposed for some aneurysm syndromes [125], the mechanisms determining the overall (or temporal) cellular response to TGF- $\beta$ (matrix deposition vs. matrix degradation) remain unclear. Accordingly, while all cell types within the aortic wall are known to respond to TGF- $\beta$, each cell type may respond differently. Thus, the combined aortic response will ultimately be deter- 
Fig. 6. Potential mechanism of TGF- $\beta$-induced changes in the cellular constituents of the vascular wall during aneurysm development. A Nonaneurysmal thoracic aorta showing normal homeostatic content of medial SMCs and adventitial fibroblasts. B Thoracic aorta during aneurysm formation. TGF- $\beta$-mediated SMC apoptosis leaves the adventitial fibroblast as the predominant endogenous cell type in the vascular wall. TGF- $\beta$ can induce adventitial fibroblasts to differentiate into myofibroblasts, conferring SMC-like characteristics including $\alpha$-smooth muscle actin expression, enhanced contractile properties, and the ability to migrate. Migrating myofibroblasts respond to TGF- $\beta$ stimulation by inducing MMP production and secretion. Thus, the resulting myofibroblast population may dominate the vascular remodeling process leading to enhanced matrix degradation.

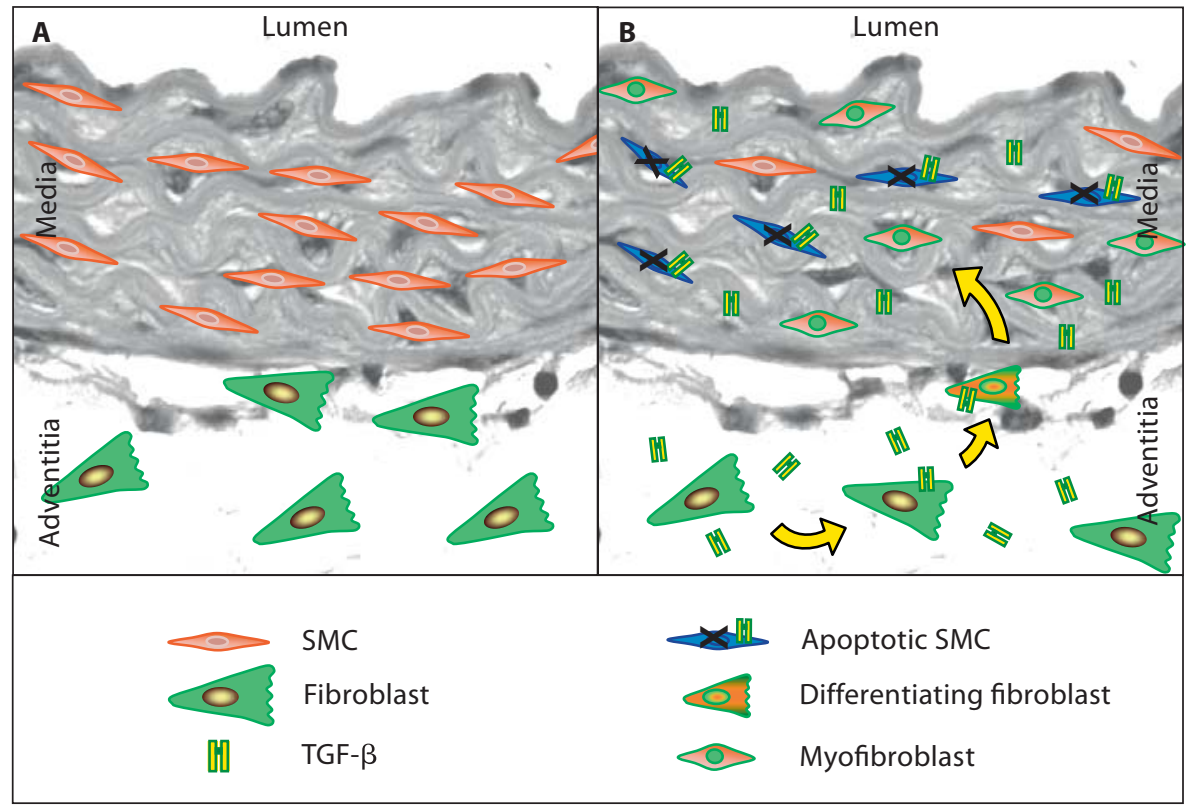

mined by the representative amounts of the constitutive cells present during aneurysm development.

There are three major endogenous cell types found within the aortic wall: (1) endothelial cells, found populating the intimal layer lining the lumen of the aorta; (2) SMCs, the predominant cell type found in the medial elastic layer, and (3) fibroblasts, found primarily in the adventitial layer. Importantly, it is well known that the cellular constituents within the aortic wall change during the course of aneurysm development. It has been well documented that aortic dilatation is accompanied by SMC apoptosis [169-172]. In fact, Fukui et al. [173] demonstrated in human abdominal aortic aneurysm specimens that high levels of TGF- $\beta$ expression colocalized with SMC markers that stained positive for fragmented DNA (TUNEL assay). This suggested that SMC apoptosis during aneurysm formation might be mediated by TGF- $\beta$ signaling pathways. Accordingly, as the aneurysm progresses, the SMC content within the aortic wall decreases, leaving fibroblasts as the predominant cell type to manage the vascular remodeling process. Thus, the degradative changes occurring within the aortic wall may be a result of the differential responses to TGF- $\beta$ mediated by the changing proportions of cellular constituents.

In addition to changes in the cellular make-up of the aortic wall during aneurysm formation, the adventitial fibroblasts themselves may also undergo phenotypic changes in response to vascular injury/stress [174]. This transition from fibroblast to myofibroblast confers SMC-like characteristics including increased expression of SMC markers (e.g. $\alpha$-smooth muscle actin) and contractile properties. Interestingly, TGF- $\beta$ may provide the signal to induce this fibroblast differentiation [175]. Shi et al. [176] demonstrated a direct correlation between autocrine TGF- $\beta$ production and the expression of $\alpha$-smooth muscle actin in adventitial fibroblasts. Likewise, Vaughan et al. [177] demonstrated that TGF- $\beta$ promoted both morphological and functional differentiation of myofibroblasts, and demonstrated that the differentiated phenotype was dependent on the presence of TGF- $\beta$; when TGF- $\beta$ was removed, the morphological markers of myofibroblast differentiation resolved. Mechanistically, studies in lung and coronary fibroblasts demonstrated that TGF- $\beta$-induced myofibroblast differentiation was dependent on enhanced signaling through the classical TGF- $\beta$ signaling pathway $[178,179]$. Pharmacologic inhibitors of ERK1/2, p38MAPK, and TGF- $\beta$ RI were used to differentiate the Smad-dependent responses from the alternative signaling pathways. This was confirmed by a study in which the overexpression of a mutant TGF- $\beta$ RI (lacking critical amino acid residues to interact with the Smads) in mammary epithelial cells failed to induce myofibroblast differentiation in response to TGF- $\beta$, but maintained an ability to activate p38MAPK [78]. Interestingly, Shi et al. $[180,181]$ demonstrated that adventitial fibroblasts from coronary arteries displayed enhanced migratory prop- 
erties characterized by increased MMP-2 and MMP-9 production. Moreover, they demonstrated a differential response from medial SMCs, in which medial explants were characterized by diminished migration and enhanced TIMP production.

Taken together, it is interesting to speculate that Smadmediated TGF- $\beta$ signaling may drive SMC apoptosis and catalyze the differentiation of fibroblasts into myofibroblasts during aneurysm development. It is then conceivable that upon acquisition of the new functional properties, the myofibroblasts may respond differently to TGF$\beta$ signals, promoting non-Smad-mediated pathways that enhance matrix-degrading enzyme production and cell migration (fig. 6). While myofibroblast transition has not been characterized in the aortic vascular wall during TAA formation, myofibroblasts have been identified in association with inflammatory aneurysms; a relatively rare subset of abdominal aortic aneurysms [182]. Accordingly, additional studies are needed to address the role of myofibroblast differentiation during TAA development, as well as the role of non-Smad-mediated signaling in myofibroblast function.

\section{Significance}

TAA disease is a potentially devastating disease process which often causes death by rupture in the absence of symptoms. There are currently no effective nonsurgical clinical treatment protocols available which will halt or reverse the aortic remodeling process once diagnosed. While it is clear that the pathological alterations in the structure and composition of the vascular ECM are associated with reduced aortic compliance and resiliency, and lead to aortic dysfunction, there remains a paucity of information regarding the regulation of specific upstream signaling intermediates and pathways involved in the remodeling process during aneurysm development. As highlighted here, mutations in key TGF- $\beta$ signaling pathway components are invariably associated with vascular pathology, and have been directly implicated in the development of ascending TAAs. While the majority of aneurysm syndromes are associated with inactivating mutations in the kinase domain of TGF- $\beta$ receptors (primarily TGF- $\beta$ RII), direct evidence has implicated enhanced TGF- $\beta$ signaling during TAA formation. As each cell type within the aortic wall is capable of responding differently to TGF- $\beta$, it is conceivable that the homeostatic balance between matrix deposition and degradation is maintained through differential cellular responses. This may be driven by TGF- $\beta$-mediated effects on the cellular composition of the aortic wall. For example, TGF- $\beta$ may induce apoptosis in the SMC population while at the same time inducing adventitial fibroblasts to transform into myofibroblasts. Thus, newly acquired cellular functions (including the production of MMPs) may work in concert with alterations in the relative number of constitutive cells, to change the overall tissue response to TGF- $\beta$, shifting the balance toward matrix degradation and aneurysm development.

These studies demonstrating enhanced signaling in the presence of mutant receptors not only speak to the complexities of TGF- $\beta$ signaling, but also emphasize the importance of continued study of TGF- $\beta$ in TAA development. Thus, it is likely that by enhancing our understanding of the complex events that mediate malignant vascular remodeling and aortic dilatation, we may also uncover interventional strategies to interrupt aneurysm formation.

\section{References}

1 Liapis CD, Paraskevas KI: The pivotal role of matrix metalloproteinases in the development of human abdominal aortic aneurysms. Vasc Med 2003;8:267-271.

$\checkmark 2$ Thompson RW, Geraghty PJ, Lee JK: Abdominal aortic aneurysms: basic mechanisms and clinical implications. Curr Probl Surg 2002;39:110-230.

-3 Isselbacher EM: Thoracic and abdominal aortic aneurysms. Circulation 2005; 111: 816-828.

4 Thompson RW: Reflections on the pathogenesis of abdominal aortic aneurysms. Cardiovasc Surg 2002;10:389-394.
5 Tamarina NA, McMillan WD, Shively VP, Pearce WH: Expression of matrix metalloproteinases and their inhibitors in aneurysms and normal aorta. Surgery 1997;122: 264-271; discussion 271-272.

-6 Bobik A: Transforming growth factor-betas and vascular disorders. Arterioscler Thromb Vasc Biol 2006;26:1712-1720.

7 Roberts AB, Sporn MB, Assoian RK, Smith JM, Roche NS, Wakefield LM, Heine UI, Liotta LA, Falanga V, Kehrl JH, et al: Transforming growth factor type beta: rapid induction of fibrosis and angiogenesis in vivo and stimulation of collagen formation in vitro. Proc Natl Acad Sci USA 1986;83:4167-4171.
8 Dennler S, Goumans MJ, ten Dijke P: Transforming growth factor beta signal transduction. J Leukoc Biol 2002;71:731-740.

-9 Massague J: TGFbeta signaling: receptors, transducers, and Mad proteins. Cell 1996;85: 947-950.

10 Massague J: How cells read TGF-beta signals. Nat Rev Mol Cell Biol 2000;1:169-178.

11 Kim ES, Kim MS, Moon A: TGF-beta-induced upregulation of MMP-2 and MMP-9 depends on p38 MAPK, but not ERK signaling in MCF10A human breast epithelial cells. Int J Oncol 2004;25:1375-1382. 
12 Laiho M, Saksela O, Keski-Oja J: Transforming growth factor beta alters plasminogen activator activity in human skin fibroblasts. Exp Cell Res 1986;164:399-407.

$\checkmark 13$ Safina A, Vandette E, Bakin AV: ALK5 promotes tumor angiogenesis by upregulating matrix metalloproteinase-9 in tumor cells. Oncogene 2007;26:2407-2422.

-14 Selvamurugan N, Kwok S, Alliston T, Reiss $\mathrm{M}$, Partridge NC: Transforming growth factor-beta 1 regulation of collagenase- 3 expression in osteoblastic cells by cross-talk between the Smad and MAPK signaling pathways and their components, Smad2 and Runx2. J Biol Chem 2004;279:19327-19334.

15 Santilli JD, Santilli SM: Diagnosis and treatment of abdominal aortic aneurysms. Am Fam Physician 1997;56:1081-1090.

-16 Bickerstaff LK, Pairolero PC, Hollier LH, Melton LJ, Van Peenen HJ, Cherry KJ, Joyce JW, Lie JT: Thoracic aortic aneurysms: a population-based study. Surgery 1982;92: 1103-1108.

17 Coady MA, Rizzo JA, Goldstein LJ, Elefteriades JA: Natural history, pathogenesis, and etiology of thoracic aortic aneurysms and dissections. Cardiol Clin 1999;17:615-635; vii.

18 Elefteriades JA, Tranquilli M, Darr U, Cardon J, Zhu BQ, Barrett P: Symptoms plus family history trump size in thoracic aortic aneurysm. Ann Thorac Surg 2005;80:10981100.

19 Guo D, Hasham S, Kuang SQ, Vaughan CJ, Boerwinkle E, Chen H, Abuelo D, Dietz HC, Basson CT, Shete SS, Milewicz DM: Familial thoracic aortic aneurysms and dissections: genetic heterogeneity with a major locus mapping to 5q13-14. Circulation 2001;103: 2461-2468.

-20 Davies RR, Goldstein LJ, Coady MA, Tittle SL, Rizzo JA, Kopf GS, Elefteriades JA: Yearly rupture or dissection rates for thoracic aortic aneurysms: simple prediction based on size. Ann Thorac Surg 2002;73:17-27; discussion 27-28.

-21 Chiesa R, Melissano G, Civilini E, de Moura ML, Carozzo A, Zangrillo A: Ten years experience of thoracic and thoracoabdominal aortic aneurysm surgical repair: lessons learned. Ann Vasc Surg 2004;18:514-520.

-22 Fleck TM, Koinig H, Czerny M, Hutschala D, Wolner E, Ehrlich M, Grabenwoger M: Impact of surgical era on outcomes of patients undergoing elective atherosclerotic ascending aortic aneurysm operations. Eur J Cardiothorac Surg 2004;26:342-347.

23 Ghansah JN, Murphy JT: Complications of major aortic and lower extremity vascular surgery. Semin Cardiothorac Vasc Anesth 2004;8:335-361.

24 Kawaharada N, Morishita K, Fukada J, Hachiro Y, Fujisawa Y, Saito T, Kurimoto Y, Abe T: Stroke in surgery of the arteriosclerotic descending thoracic aortic aneurysms: influence of cross-clamping technique of the aorta. Eur J Cardiothorac Surg 2005;27:622625.
25 Alexander JJ: The pathobiology of aortic an eurysms. J Surg Res 2004;117:163-175.

26 Elefteriades JA: Natural history of thoracic aortic aneurysms: indications for surgery, and surgical versus nonsurgical risks. Ann Thorac Surg 2002;74:S1877-S1880; discussion S1892-S1898.

27 Davies RR, Gallo A, Coady MA, Tellides G, Botta DM, Burke B, Coe MP, Kopf GS, Elefteriades JA: Novel measurement of relative aortic size predicts rupture of thoracic aortic aneurysms. Ann Thorac Surg 2006;81:169177.

28 Dobrin PB, Mrkvicka R: Failure of elastin or collagen as possible critical connective tissue alterations underlying aneurysmal dilatation. Cardiovasc Surg 1994;2:484-488.

29 Allaire E, Hasenstab D, Kenagy RD, Starcher B, Clowes MM, Clowes AW: Prevention of aneurysm development and rupture by local overexpression of plasminogen activator inhibitor-1. Circulation 1998;98:249-255.

- 30 Boyle JR, McDermott E, Crowther M, Wills AD, Bell PR, Thompson MM: Doxycycline inhibits elastin degradation and reduces metalloproteinase activity in a model of aneurysmal disease. J Vasc Surg 1998;27:354361.

31 Carrell TW, Smith A, Burnand KG: Experimental techniques and models in the study of the development and treatment of abdominal aortic aneurysm. Br J Surg 1999;86:305312.

32 Chiou AC, Chiu B, Pearce WH: Murine aortic aneurysm produced by periarterial application of calcium chloride. J Surg Res 2001; 99:371-376.

- 33 Freestone T, Turner RJ, Higman DJ, Lever MJ, Powell JT: Influence of hypercholesterolemia and adventitial inflammation on the development of aortic aneurysm in rabbits. Arterioscler Thromb Vasc Biol 1997;17:10-17.

-34 Gertz SD, Kurgan A, Eisenberg D: Aneurysm of the rabbit common carotid artery induced by periarterial application of calcium chloride in vivo. J Clin Invest 1988;81:649656.

35 Longo GM, Xiong W, Greiner TC, Zhao Y, Fiotti N, Baxter BT: Matrix metalloproteinases 2 and 9 work in concert to produce aortic aneurysms. J Clin Invest 2002;110:625-632.

-36 Pyo R, Lee JK, Shipley JM, Curci JA, Mao D, Ziporin SJ, Ennis TL, Shapiro SD, Senior RM, Thompson RW: Targeted gene disruption of matrix metalloproteinase-9 (gelatinase B) suppresses development of experimental abdominal aortic aneurysms. J Clin Invest 2000;105:1641-1649.

37 Barbour JR, Spinale FG, Ikonomidis JS: Proteinase systems and thoracic aortic aneurysm progression. J Surg Res 2007;139:292307.
38 Ikonomidis JS, Barbour JR, Amani Z, Stroud RE, Herron AR, McClister DM Jr, Camens SE, Lindsey ML, Mukherjee R, Spinale FG: Effects of deletion of the matrix metalloproteinase 9 gene on development of murine thoracic aortic aneurysms. Circulation 2005; 112:I242-I248.

39 Ikonomidis JS, Gibson WC, Butler JE, McClister DM, Sweterlitsch SE, Thompson RP, Mukherjee R, Spinale FG: Effects of deletion of the tissue inhibitor of matrix metalloproteinases-1 gene on the progression of murine thoracic aortic aneurysms. Circulation 2004; 110:II268-II273.

40 Jones JA, Barbour JR, Lowry AS, Bouges S, Beck C, McClister DM Jr, Mukherjee R, Ikonomidis JS: Spatiotemporal expression and localization of matrix metalloproteinase- 9 in a murine model of thoracic aortic aneurysm. J Vasc Surg 2006;44:1314-1321.

- 41 Longo GM, Buda SJ, Fiotta N, Xiong W, Griener T, Shapiro S, Baxter BT: MMP-12 has a role in abdominal aortic aneurysms in mice. Surgery 2005; 137:457-462.

42 Brophy CM, Marks WH, Reilly JM, Tilson MD: Decreased tissue inhibitor of metalloproteinases (TIMP) in abdominal aortic aneurysm tissue: a preliminary report. J Surg Res 1991;50:653-657.

-43 Koullias GJ, Korkolis DP, Ravichandran P, Psyrri A, Hatzaras I, Elefteriades JA: Tissue microarray detection of matrix metalloproteinases, in diseased tricuspid and bicuspid aortic valves with or without pathology of the ascending aorta. Eur J Cardiothorac Surg 2004;26:1098-1103.

44 Bertolino P, Deckers M, Lebrin F, ten Dijke $\mathrm{P}$ : Transforming growth factor-beta signal transduction in angiogenesis and vascular disorders. Chest 2005; 128:585S-590S.

45 Feng XH, Derynck R: Specificity and versatility in TGF-beta signaling through Smads. Annu Rev Cell Dev Biol 2005;21:659-693.

46 Massague J, Chen YG: Controlling TGF-beta signaling. Genes Dev 2000;14:627-644.

-47 Moustakas A, Heldin CH: Non-Smad TGFbeta signals. J Cell Sci 2005;118:3573-3584.

48 Moustakas A, Souchelnytskyi S, Heldin CH: Smad regulation in TGF-beta signal transduction. J Cell Sci 2001;114:4359-4369.

49 Bartram U, Speer CP: The role of transforming growth factor beta in lung development and disease. Chest 2004;125:754-765.

50 Bataller R, Brenner DA: Liver fibrosis. J Clin Invest 2005;115:209-218.

51 Lijnen PJ, Petrov VV, Fagard RH: Induction of cardiac fibrosis by transforming growth factor-beta(1). Mol Genet Metab 2000;71: 418-435.

-52 Wrana JL, Attisano L, Carcamo J, Zentella A, Doody J, Laiho M, Wang XF, Massague J: TGF beta signals through a heteromeric protein kinase receptor complex. Cell 1992;71: 1003-1014. 
53 Wrana JL, Attisano L, Wieser R, Ventura F, Massague J: Mechanism of activation of the TGF-beta receptor. Nature 1994;370:341347.

54 Leivonen SK, Chantry A, Hakkinen L, Han J, Kahari VM: Smad3 mediates transforming growth factor-beta-induced collagenase-3 (matrix metalloproteinase-13) expression in human gingival fibroblasts. Evidence for cross-talk between Smad3 and p38 signaling pathways. J Biol Chem 2002;277:4633846346.

- 55 Ottaviano AJ, Sun L, Ananthanarayanan V, Munshi HG: Extracellular matrix-mediated membrane-type 1 matrix metalloproteinase expression in pancreatic ductal cells is regulated by transforming growth factor-beta1. Cancer Res 2006;66:7032-7040.

-56 Kahari VM, Olsen DR, Rhudy RW, Carrillo $\mathrm{P}$, Chen YQ, Uitto J: Transforming growth factor-beta up-regulates elastin gene expression in human skin fibroblasts. Evidence for post-transcriptional modulation. Lab Invest 1992;66:580-588.

>57 Kucich U, Rosenbloom JC, Abrams WR, Rosenbloom J: Transforming growth factorbeta stabilizes elastin mRNA by a pathway requiring active Smads, protein kinase Cdelta, and p38. Am J Respir Cell Mol Biol 2002;26:183-188.

58 Kwak HJ, Park MJ, Cho H, Park CM, Moon SI, Lee HC, Park IC, Kim MS, Rhee $\mathrm{CH}$, Hong SI: Transforming growth factor-betal induces tissue inhibitor of metalloproteinase-1 expression via activation of extracellular signal-regulated kinase and Spl in human fibrosarcoma cells. Mol Cancer Res 2006;4:209-220.

59 García-Alvarez J, Ramirez R, Checa M, Nuttall RK, Sampieri CL, Edwards DR, Selman M, Pardo A: Tissue inhibitor of metalloproteinase-3 is up-regulated by transforming growth factor-betal in vitro and expressed in fibroblastic foci in vivo in idiopathic pulmonary fibrosis. Exp Lung Res 2006;32:201214.

60 de Larco JE, Todaro GJ: Growth factors from murine sarcoma virus-transformed cells. Proc Natl Acad Sci USA 1978;75:40014005.

-61 Roberts AB, Frolik CA, Anzano MA, Sporn $\mathrm{MB}$ : Transforming growth factors from neoplastic and nonneoplastic tissues. Fed Proc 1983;42:2621-2626.

-62 Roberts AB, Anzano MA, Wakefield LM, Roche NS, Stern DF, Sporn MB: Type beta transforming growth factor: a bifunctional regulator of cellular growth. Proc Natl Acad Sci USA 1985;82:119-123.

-63 Suszko MI, Woodruff TK: Cell-specificity of transforming growth factor-beta response is dictated by receptor bioavailability. $\mathrm{J} \mathrm{Mol}$ Endocrinol 2006;36:591-600.
64 Lopez-Casillas F, Payne HM, Andres JL, Massague J: Betaglycan can act as a dual modulator of TGF-beta access to signaling receptors: mapping of ligand binding and GAG attachment sites. J Cell Biol 1994;124: 557-568.

65 Wang XF, Lin HY, Ng-Eaton E, Downward J, Lodish HF, Weinberg RA: Expression cloning and characterization of the TGF-beta type III receptor. Cell 1991;67:797-805.

66 Xu L: Regulation of Smad activities. Biochim Biophys Acta 2006;1759:503-513.

67 Wicks SJ, Grocott T, Haros K, Maillard M, ten Dijke P, Chantry A: Reversible ubiquitination regulates the Smad/TGF-beta signalling pathway. Biochem Soc Trans 2006 34:761-763.

-68 Coucke PJ, Willaert A, Wessels MW, Callewaert B, Zoppi N, De Backer J, Fox JE, Mancini GM, Kambouris M, Gardella R, Facchetti F, Willems PJ, Forsyth R, Dietz HC, Barlati S, Colombi M, Loeys B, De Paepe A Mutations in the facilitative glucose transporter GLUT10 alter angiogenesis and cause arterial tortuosity syndrome. Nat Genet 2006;38:452-457.

69 Park SH: Fine tuning and cross-talking of TGF-beta signal by inhibitory Smads. J Biochem Mol Biol 2005;38:9-16.

70 Imamura T, Takase M, Nishihara A, Oeda E, Hanai J, Kawabata M, Miyazono K: Smad6 inhibits signalling by the TGF-beta superfamily. Nature 1997;389:622-626.

71 Hata A, Lagna G, Massague J, HemmatiBrivanlou A: Smad6 inhibits BMP/Smad1 signaling by specifically competing with the Smad4 tumor suppressor. Genes Dev 1998, 12:186-197.

72 Ebisawa T, Fukuchi M, Murakami G, Chiba $\mathrm{T}$, Tanaka K, Imamura $\mathrm{T}$, Miyazono $\mathrm{K}$ : Smurf1 interacts with transforming growth factor-beta type I receptor through Smad7 and induces receptor degradation. J Biol Chem 2001;276:12477-12480.

73 Kavsak P, Rasmussen RK, Causing CG, Bonni S, Zhu H, Thomsen GH, Wrana JL: Smad7 binds to Smurf2 to form an E3 ubiquitin ligase that targets the TGF beta receptor for degradation. Mol Cell 2000;6:1365-1375.

74 Moren A, Hellman U, Inada Y, Imamura T, Heldin CH, Moustakas A: Differential ubiquitination defines the functional status of the tumor suppressor Smad4. J Biol Chem 2003;278:33571-33582.

75 Moren A, Imamura T, Miyazono K, Heldin $\mathrm{CH}$, Moustakas A: Degradation of the tumor suppressor Smad4 by WW and HECT domain ubiquitin ligases. J Biol Chem 2005; 280:22115-22123.

76 Derynck R, Zhang YE: Smad-dependent and Smad-independent pathways in TGF-beta family signalling. Nature 2003;425:577-584.

77 Shi Y, Massague J: Mechanisms of TGF-beta signaling from cell membrane to the nucleus. Cell 2003;113:685-700.
$78 \mathrm{Yu}$ L, Hebert MC, Zhang YE: TGF-beta receptor-activated p38 MAP kinase mediates Smad-independent TGF-beta responses. EMBO J 2002;21:3749-3759.

79 Choy L, Derynck R: The type II transforming growth factor (TGF)-beta receptor-interacting protein TRIP-1 acts as a modulator of the TGF-beta response. J Biol Chem 1998; 273:31455-31462

-80 Ozdamar B, Bose R, Barrios-Rodiles M, Wang HR, Zhang Y, Wrana JL: Regulation of the polarity protein Par6 by TGFbeta receptors controls epithelial cell plasticity. Science 2005;307:1603-1609.

$>81$ Dumont N, Bakin AV, Arteaga CL: Autocrine transforming growth factor-beta signaling mediates Smad-independent motility in human cancer cells. J Biol Chem 2003;278: 3275-3285.

82 Griswold-Prenner I, Kamibayashi C, Maruoka EM, Mumby MC, Derynck R: Physical and functional interactions between type I transforming growth factor beta receptors and Balpha, a WD-40 repeat subunit of phosphatase 2A. Mol Cell Biol 1998;18:65956604.

83 Itoh S, Thorikay M, Kowanetz M, Moustakas A, Itoh F, Heldin CH, ten Dijke P: Elucidation of Smad requirement in transforming growth factor-beta type I receptor-induced responses. J Biol Chem 2003;278:3751-3761.

84 Wilkes MC, Murphy SJ, Garamszegi N, Leof EB: Cell-type-specific activation of PAK2 by transforming growth factor beta independent of Smad2 and Smad3. Mol Cell Biol 2003;23:8878-8889.

85 Hocevar BA, Brown TL, Howe PH: TGF-beta induces fibronectin synthesis through a cJun N-terminal kinase-dependent, Smad4independent pathway. EMBO J 1999;18: 1345-1356.

-86 Imamichi Y, Waidmann O, Hein R, Eleftheriou P, Giehl K, Menke A: TGF beta-induced focal complex formation in epithelial cells is mediated by activated ERK and JNK MAP kinases and is independent of Smad4. Biol Chem 2005;386:225-236.

87 Remy I, Montmarquette A, Michnick SW: PKB/Akt modulates TGF-beta signalling through a direct interaction with Smad3. Nat Cell Biol 2004;6:358-365.

-88 Runyan CE, Schnaper HW, Poncelet AC: The phosphatidylinositol 3-kinase/Akt pathway enhances Smad3-stimulated mesangial cell collagen I expression in response to transforming growth factor-beta1. J Biol Chem 2004;279:2632-2639.

89 Yakymovych I, Ten Dijke P, Heldin CH, Souchelnytskyi S: Regulation of Smad signaling by protein kinase C. FASEB J 2001;15: 553-555.

90 Ignotz RA, Massague J: Transforming growth factor-beta stimulates the expression of fibronectin and collagen and their incorporation into the extracellular matrix. J Biol Chem 1986;261:4337-4345. 
-91 Varga J, Jimenez SA: Stimulation of normal human fibroblast collagen production and processing by transforming growth factorbeta. Biochem Biophys Res Commun 1986; 138:974-980.

-92 Varga J, Rosenbloom J, Jimenez SA: Transforming growth factor beta (TGF beta) causes a persistent increase in steady-state amounts of type I and type III collagen and fibronectin mRNAs in normal human dermal fibroblasts. Biochem J 1987;247:597604.

\$9 Wrana JL, Maeno M, Hawrylyshyn B, Yao KL, Domenicucci C, Sodek J: Differential effects of transforming growth factor-beta on the synthesis of extracellular matrix proteins by normal fetal rat calvarial bone cell populations. J Cell Biol 1988;106:915924.

-94 Eghbali M, Tomek R, Sukhatme VP, Woods C, Bhambi B: Differential effects of transforming growth factor-beta 1 and phorbol myristate acetate on cardiac fibroblasts. Regulation of fibrillar collagen mRNAs and expression of early transcription factors. Circ Res 1991;69:483-490.

$\$ 95$ Ghosh AK: Factors involved in the regulation of type I collagen gene expression: implication in fibrosis. Exp Biol Med (Maywood) 2002;227:301-314.

\$9 Verrecchia F, Mauviel A: TGF-beta and TNF-alpha: antagonistic cytokines controlling type I collagen gene expression. Cell Signal 2004;16:873-880.

$\checkmark 97$ Smith JD, Bryant SR, Couper LL, Vary CP, Gotwals PJ, Koteliansky VE, Lindner V: Soluble transforming growth factor-beta type II receptor inhibits negative remodeling, fibroblast transdifferentiation, and intimal lesion formation but not endothelial growth. Circ Res 1999;84:1212-1222.

-98 Zhang Z, Li XJ, Liu Y, Zhang X, Li YY, Xu WS: Recombinant human decorin inhibits cell proliferation and downregulates TGFbetal production in hypertrophic scar fibroblasts. Burns 2007;33:634-641.

$\$ 99$ Ihn H: Pathogenesis of fibrosis: role of TGF-beta and CTGF. Curr Opin Rheumatol 2002;14:681-685.

100 Verrecchia F, Mauviel A: Transforming growth factor-beta and fibrosis. World Gastroenterol 2007;13:3056-3062.

101 Moussad EE, Brigstock DR: Connective tissue growth factor: what's in a name? Mol Genet Metab 2000;71:276-292.

- 102 Lijnen HR: Plasmin and matrix metalloproteinases in vascular remodeling. Thromb Haemost 2001;86:324-333.

-103 Keski-Oja J, Raghow R, Sawdey M, Loskutoff DJ, Postlethwaite AE, Kang AH, Moses HL: Regulation of mRNAs for type-1 plasminogen activator inhibitor, fibronectin, and type I procollagen by transforming growth factor-beta. Divergent responses in lung fibroblasts and carcinoma cells. J Biol Chem 1988;263:3111-3115.
104 Chakraborti S, Mandal M, Das S, Mandal A, Chakraborti T: Regulation of matrix metalloproteinases: an overview. Mol Cell Biochem 2003;253:269-285.

105 Yan C, Boyd DD: Regulation of matrix metalloproteinase gene expression. J Cell Physiol 2007;211:19-26.

106 Kerr LD, Miller DB, Matrisian LM: TGFbeta 1 inhibition of transin/stromelysin gene expression is mediated through a Fos binding sequence. Cell 1990;61:267-278.

107 Edwards DR, Murphy G, Reynolds JJ, Whitham SE, Docherty AJ, Angel P, Heath JK: Transforming growth factor beta modulates the expression of collagenase and metalloproteinase inhibitor. EMBO J 1987; 6:1899-1904.

108 Dai J, Losy F, Guinault AM, Pages C, Anegon I, Desgranges P, Becquemin JP, Allaire E: Overexpression of transforming growth factor-beta1 stabilizes already-formed aortic aneurysms: a first approach to induction of functional healing by endovascular gene therapy. Circulation 2005;112:1008-1015.

109 Bobik A, Agrotis A, Kanellakis P, Dilley R, Krushinsky A, Smirnov V, Tararak E, Condron M, Kostolias G: Distinct patterns of transforming growth factor-beta isoform and receptor expression in human atherosclerotic lesions. Colocalization implicates TGF-beta in fibrofatty lesion development. Circulation 1999;99:2883-2891.

$>110$ Cipollone F, Fazia M, Mincione G, Iezzi A, Pini B, Cuccurullo C, Ucchino S, Spigonardo F, Di Nisio M, Cuccurullo F, Mezzetti A, Porreca E: Increased expression of transforming growth factor-betal as a stabilizing factor in human atherosclerotic plaques. Stroke 2004;35:2253-2257.

-111 Lutgens E, Gijbels M, Smook M, Heeringa P, Gotwals P, Koteliansky VE, Daemen MJ: Transforming growth factor-beta mediates balance between inflammation and fibrosis during plaque progression. Arterioscler Thromb Vasc Biol 2002;22:975-982.

112 Syed M, Lesch M: Coronary artery aneurysm: a review. Prog Cardiovasc Dis 1997; 40:77-84.

113 Gaine SP, Rubin LJ: Primary pulmonary hypertension. Lancet 1998;352:719-725.

114 Loscalzo J: Genetic clues to the cause of primary pulmonary hypertension. N Engl J Med 2001;345:367-371.

115 Newman JH, Trembath RC, Morse JA, Grunig E, Loyd JE, Adnot S, Coccolo F, Ventura C, Phillips JA, 3rd, Knowles JA, Janssen B, Eickelberg O, Eddahibi S, Herve P, Nichols WC, Elliott G: Genetic basis of pulmonary arterial hypertension: current understanding and future directions. J Am Coll Cardiol 2004;43:33S-39S.
116 Rudarakanchana N, Flanagan JA, Chen H, Upton PD, Machado R, Patel D, Trembath RC, Morrell NW: Functional analysis of bone morphogenetic protein type II receptor mutations underlying primary pulmonary hypertension. Hum Mol Genet 2002; 11:1517-1525.

117 Cheifetz S, Bellon T, Cales C, Vera S, Bernabeu C, Massague J, Letarte M: Endoglin is a component of the transforming growth factor-beta receptor system in human endothelial cells. J Biol Chem 1992;267:1902719030.

- 118 You HJ, Bruinsma MW, How T, Ostrander JH, Blobe GC: The type III TGF-beta receptor signals through both Smad 3 and the $\mathrm{p} 38$ MAP kinase pathways to contribute to inhibition of cell proliferation. Carcinogenesis 2007;28:2491-2500.

119 Johnson DW, Berg JN, Baldwin MA, Gallione CJ, Marondel I, Yoon SJ, Stenzel TT, Speer M, Pericak-Vance MA, Diamond A, Guttmacher AE, Jackson CE, Attisano L, Kucherlapati R, Porteous ME, Marchuk DA: Mutations in the activin receptor-like kinase 1 gene in hereditary haemorrhagic telangiectasia type 2. Nat Genet 1996;13: 189-195.

120 ten Dijke P, Yamashita H, Ichijo H, Franzen P, Laiho M, Miyazono K, Heldin CH: Characterization of type I receptors for transforming growth factor-beta and activin. Science 1994;264:101-104.

121 Oh SP, Seki T, Goss KA, Imamura T, Yi Y, Donahoe PK, Li L, Miyazono K, ten Dijke P, Kim S, Li E: Activin receptor-like kinase 1 modulates transforming growth factorbeta 1 signaling in the regulation of angiogenesis. Proc Natl Acad Sci USA 2000;97: 2626-2631.

122 Choke E, Cockerill GW, Dawson J, Wilson RW, Jones A, Loftus IM, Thompson MM: Increased angiogenesis at the site of abdominal aortic aneurysm rupture. Ann NY Acad Sci 2006;1085:315-319.

- 123 Miwa K, Nakashima H, Aoki M, Miyake T, Kawasaki T, Iwai M, Oishi M, Kataoka K, Ohgi S, Ogihara T, Kaneda Y, Morishita R: Inhibition of ets, an essential transcription factor for angiogenesis, to prevent the development of abdominal aortic aneurysm in a rat model. Gene Ther 2005;12:11091118.

124 Paik DC, Fu C, Bhattacharya J, Tilson MD: Ongoing angiogenesis in blood vessels of the abdominal aortic aneurysm. Exp Mol Med 2004;36:524-533.

125 Dietz HC, Loeys B, Carta L, Ramirez F: Recent progress towards a molecular understanding of Marfan syndrome. Am J Med Genet C Semin Med Genet 2005;139:4-9.

-126 Lee B, Godfrey M, Vitale E, Hori H, Mattei MG, Sarfarazi M, Tsipouras P, Ramirez F, Hollister DW: Linkage of Marfan syndrome and a phenotypically related disorder to two different fibrillin genes. Nature 1991; 352:330-334. 
-127 Silverman DI, Gray J, Roman MJ, Bridges A, Burton K, Boxer M, Devereux RB, Tsipouras P: Family history of severe cardiovascular disease in Marfan syndrome is associated with increased aortic diameter and decreased survival. J Am Coll Cardiol 1995; 26:1062-1067.

-128 van Karnebeek CD, Naeff MS, Mulder BJ, Hennekam RC, Offringa M: Natural history of cardiovascular manifestations in Marfan syndrome. Arch Dis Child 2001;84: 129-137.

129 Ramirez F: Fibrillln mutations in Marfan syndrome and related phenotypes. Curr Opin Genet Dev 1996;6:309-315.

$\checkmark 130$ Ramirez F, Pereira L: The fibrillins. Int J Biochem Cell Biol 1999;31:255-259.

-131 Ramirez F, Sakai LY, Dietz HC, Rifkin DB: Fibrillin microfibrils: multipurpose extracellular networks in organismal physiology. Physiol Genomics 2004;19:151-154.

-132 Bunton TE, Biery NJ, Myers L, Gayraud B, Ramirez F, Dietz HC: Phenotypic alteration of vascular smooth muscle cells precedes elastolysis in a mouse model of Marfan syndrome. Circ Res 2001;88:37-43.

133 Pereira L, Lee SY, Gayraud B, Andrikopoulos K, Shapiro SD, Bunton T, Biery NJ, Dietz HC, Sakai LY, Ramirez F: Pathogenetic sequence for aneurysm revealed in mice underexpressing fibrillin-1. Proc Natl Acad Sci USA 1999;96:3819-3823.

$\checkmark 134$ Kaartinen V, Warburton D: Fibrillin controls TGF-beta activation. Nat Genet 2003; 33:331-332.

-135 Annes JP, Munger JS, Rifkin DB: Making sense of latent TGFbeta activation. J Cell Sci 2003;116:217-224.

-136 Chaudhry SS, Cain SA, Morgan A, Dallas SL, Shuttleworth CA, Kielty CM: Fibrillin1 regulates the bioavailability of TGFbeta1. J Cell Biol 2007;176:355-367.

-137 Charbonneau NL, Ono RN, Corson GM, Keene DR, Sakai LY: Fine tuning of growth factor signals depends on fibrillin microfibril networks. Birth Defects Res C Embryo Today 2004;72:37-50.

$\checkmark 138$ Isogai Z, Ono RN, Ushiro S, Keene DR, Chen Y, Mazzieri R, Charbonneau NL, Reinhardt DP, Rifkin DB, Sakai LY: Latent transforming growth factor beta-binding protein 1 interacts with fibrillin and is a microfibril-associated protein. J Biol Chem 2003;278:2750-2757.

139 Koli K, Saharinen J, Hyytiainen M, Penttinen C, Keski-Oja J: Latency, activation, and binding proteins of TGF-beta. Microsc Res Tech 2001;52:354-362.

- 140 Neptune ER, Frischmeyer PA, Arking DE, Myers L, Bunton TE, Gayraud B, Ramirez F, Sakai LY, Dietz HC: Dysregulation of TGF-beta activation contributes to pathogenesis in Marfan syndrome. Nat Genet 2003;33:407-411.
141 Habashi JP, Judge DP, Holm TM, Cohn RD, Loeys BL, Cooper TK, Myers L, Klein EC, Liu G, Calvi C, Podowski M, Neptune ER, Halushka MK, Bedja D, Gabrielson K, Rifkin DB, Carta L, Ramirez F, Huso DL, Dietz HC: Losartan, an AT1 antagonist, prevents aortic aneurysm in a mouse model of Marfan syndrome. Science 2006;312: 117-121.

142 Beighton P, de Paepe A, Danks D, Finidori G, Gedde-Dahl T, Goodman R, Hall JG, Hollister DW, Horton W, McKusick VA, et al: International Nosology of Heritable Disorders of Connective Tissue, Berlin, 1986. Am J Med Genet 1988;29:581-594.

143 De Paepe A, Devereux RB, Dietz HC, Hennekam RC, Pyeritz RE: Revised diagnostic criteria for the Marfan syndrome. Am J Med Genet 1996;62:417-426.

144 Rose PS, Levy HP, Ahn NU, Sponseller PD, Magyari T, Davis J, Francomano CA: A comparison of the Berlin and Ghent nosologies and the influence of dural ectasia in the diagnosis of Marfan syndrome. Genet Med 2000;2:278-282.

145 Collod G, Babron MC, Jondeau G, Coulon M, Weissenbach J, Dubourg O, Bourdarias JP, Bonaiti-Pellie C, Junien C, Boileau C: A second locus for Marfan syndrome maps to chromosome 3p24.2-p25. Nat Genet 1994; 8:264-268

146 Dietz H, Francke U, Furthmayr H, Francomano C, De Paepe A, Devereux R, Ramirez F, Pyeritz R: The question of heterogeneity in Marfan syndrome. Nat Genet 1995;9: 228-231.

147 Gilchrist DM: Marfan syndrome or Marfan-like connective-tissue disorder. Am J Hum Genet 1994;54:553-554.

148 Boileau C, Jondeau G, Babron MC, Coulon M, Alexandre JA, Sakai L, Melki J, Delorme G, Dubourg O, Bonaiti-Pellie C, et al: Autosomal dominant Marfan-like connectivetissue disorder with aortic dilation and skeletal anomalies not linked to the fibrillin genes. Am J Hum Genet 1993;53:4654.

149 Mizuguchi T, Collod-Beroud G, Akiyama T, Abifadel M, Harada N, Morisaki T, Allard D, Varret M, Claustres M, Morisaki H, Ihara M, Kinoshita A, Yoshiura K, Junien C, Kajii T, Jondeau G, Ohta T, Kishino T, Furukawa Y, Nakamura Y, Niikawa N, Boileau C, Matsumoto N: Heterozygous TGFBR2 mutations in Marfan syndrome. Nat Genet 2004;36:855-860.

150 Biddinger A, Rocklin M, Coselli J, Milewicz DM: Familial thoracic aortic dilatations and dissections: a case control study. J Vasc Surg 1997;25:506-511.
151 Loeys BL, Schwarze U, Holm T, Callewaert BL, Thomas GH, Pannu H, De Backer JF, Oswald GL, Symoens S, Manouvrier S, Roberts AE, Faravelli F, Greco MA, Pyeritz RE, Milewicz DM, Coucke PJ, Cameron DE, Braverman AC, Byers PH, De Paepe AM, Dietz HC: Aneurysm syndromes caused by mutations in the TGF-beta receptor. N Engl J Med 2006;355:788-798.

152 Pannu H, Avidan N, Tran-Fadulu V, Milewicz DM: Genetic basis of thoracic aortic aneurysms and dissections: potential relevance to abdominal aortic aneurysms. Ann NY Acad Sci 2006;1085:242-255.

153 Zhu L, Vranckx R, Khau Van Kien P, Lalande A, Boisset N, Mathieu F, Wegman M, Glancy L, Gasc JM, Brunotte F, Bruneval P, Wolf JE, Michel JB, Jeunemaitre X: Mutations in myosin heavy chain 11 cause a syndrome associating thoracic aortic aneurysm/aortic dissection and patent ductus arteriosus. Nat Genet 2006;38:343-349.

154 Guo DC, Pannu H, Tran-Fadulu V, Papke CL, Yu RK, Avidan N, Bourgeois S, Estrera AL, Safi HJ, Sparks E, Amor D, Ades L, McConnell V, Willoughby CE, Abuelo D, Willing M, Lewis RA, Kim DH, Scherer S, Tung PP, Ahn C, Buja LM, Raman CS, Shete SS, Milewicz DM: Mutations in smooth muscle alpha-actin (ACTA2) lead to thoracic aortic aneurysms and dissections. Nat Genet 2007;39:1488-1493.

155 Hasham SN, Willing MC, Guo DC, Muilenburg A, He R, Tran VT, Scherer SE, Shete SS, Milewicz DM: Mapping a locus for familial thoracic aortic aneurysms and dissections (TAAD2) to 3p24-25. Circulation 2003;107:3184-3190.

156 Matyas G, Arnold E, Carrel T, Baumgartner D, Boileau C, Berger W, Steinmann B: Identification and in silico analyses of novel TGFBR1 and TGFBR2 mutations in Marfan syndrome-related disorders. Hum $\mathrm{Mu}-$ tat 2006;27:760-769.

157 Pannu H, Tran-Fadulu V, Milewicz DM: Genetic basis of thoracic aortic aneurysms and aortic dissections. Am J Med Genet C Semin Med Genet 2005;139:10-16.

158 Pannu H, Fadulu VT, Chang J, Lafont A, Hasham SN, Sparks E, Giampietro PF, Zaleski C, Estrera AL, Safi HJ, Shete S, Willing MC, Raman CS, Milewicz DM: Mutations in transforming growth factor-beta receptor type II cause familial thoracic aortic aneurysms and dissections. Circulation 2005; 112:513-520.

159 Loeys BL, Chen J, Neptune ER, Judge DP, Podowski M, Holm T, Meyers J, Leitch CC, Katsanis N, Sharifi N, Xu FL, Myers LA, Spevak PJ, Cameron DE, De Backer J, Hellemans J, Chen Y, Davis EC, Webb CL, Kress W, Coucke P, Rifkin DB, De Paepe AM, Dietz HC: A syndrome of altered cardiovascular, craniofacial, neurocognitive and skeletal development caused by mutations in TGFBR1 or TGFBR2. Nat Genet 2005;37:275-281. 
160 Singh KK, Rommel K, Mishra A, Karck M, Haverich A, Schmidtke J, Arslan-Kirchner M: TGFBR1 and TGFBR2 mutations in patients with features of Marfan syndrome and Loeys-Dietz syndrome. Hum Mutat 2006;27:770-777.

-161 Superti-Furga A, Gugler E, Gitzelmann R, Steinmann B: Ehlers-Danlos syndrome type IV: a multi-exon deletion in one of the two COL3A1 alleles affecting structure, stability, and processing of type III procollagen. J Biol Chem 1988;263:6226-6232.

-162 Boutouyrie P, Germain DP, Fiessinger JN, Laloux B, Perdu J, Laurent S: Increased carotid wall stress in vascular Ehlers-Danlos syndrome. Circulation 2004;109:15301535.

163 Denton CP, Zheng B, Evans LA, Shi-wen X, Ong VH, Fisher I, Lazaridis K, Abraham DJ, Black CM, de Crombrugghe B: Fibroblast-specific expression of a kinase-deficient type II transforming growth factor beta (TGFbeta) receptor leads to paradoxical activation of TGFbeta signaling pathways with fibrosis in transgenic mice. J Biol Chem 2003;278:25109-25119.

-164 Wong SH, Hamel L, Chevalier S, Philip A: Endoglin expression on human microvascular endothelial cells association with betaglycan and formation of higher order complexes with TGF-beta signalling receptors. Eur J Biochem 2000;267:5550-5560.

165 Di Guglielmo GM, Le Roy C, Goodfellow AF, Wrana JL: Distinct endocytic pathways regulate TGF-beta receptor signalling and turnover. Nat Cell Biol 2003;5:410-421.

- 166 Nakao A, Afrakhte M, Moren A, Nakayama T, Christian JL, Heuchel R, Itoh S, Kawabata M, Heldin NE, Heldin CH, ten Dijke P: Identification of Smad7, a TGFbeta-inducible antagonist of TGF-beta signalling. Nature 1997;389:631-635.
167 Engel ME, McDonnell MA, Law BK, Moses HL: Interdependent SMAD and JNK signaling in transforming growth factor-betamediated transcription. J Biol Chem 1999; 274:37413-37420.

168 Lee KS, Hong SH, Bae SC: Both the Smad and p38 MAPK pathways play a crucial role in Runx2 expression following induction by transforming growth factor-beta and bone morphogenetic protein. Oncogene 2002;21:7156-7163.

169 Henderson EL, Geng YJ, Sukhova GK, Whittemore AD, Knox J, Libby P: Death of smooth muscle cells and expression of mediators of apoptosis by $\mathrm{T}$ lymphocytes in human abdominal aortic aneurysms. Circulation 1999;99:96-104.

170 Lopez-Candales A, Holmes DR, Liao S, Scott MJ, Wickline SA, Thompson RW: Decreased vascular smooth muscle cell density in medial degeneration of human abdominal aortic aneurysms. Am J Pathol 1997;150:993-1007.

171 Sho E, Sho M, Nanjo H, Kawamura K, Masuda H, Dalman RL: Comparison of celltype-specific vs transmural aortic gene expression in experimental aneurysms. J Vasc Surg 2005;41:844-852.

172 Thompson RW, Liao S, Curci JA: Vascular smooth muscle cell apoptosis in abdominal aortic aneurysms. Coron Artery Dis 1997; 8:623-631.

173 Fukui D, Miyagawa S, Soeda J, Tanaka K, Urayama H, Kawasaki S: Overexpression of transforming growth factor betal in smooth muscle cells of human abdominal aortic aneurysm. Eur J Vasc Endovasc Surg 2003;25:540-545.

174 Zalewski A, Shi Y: Vascular myofibroblasts. Lessons from coronary repair and remodeling. Arterioscler Thromb Vasc Biol 1997; 17: 417-422.

175 Willis BC, Borok Z: TGF-beta-induced EMT: mechanisms and implications for fibrotic lung disease. Am J Physiol Lung Cell Mol Physiol 2007;293:L525-L534.
176 Shi Y, O’Brien JE Jr, Fard A, Zalewski A: Transforming growth factor-beta 1 expression and myofibroblast formation during arterial repair. Arterioscler Thromb Vasc Biol 1996;16:1298-1305.

177 Vaughan MB, Howard EW, Tomasek JJ: Transforming growth factor-betal promotes the morphological and functional differentiation of the myofibroblast. Exp Cell Res 2000;257:180-189.

178 Hu Y, Peng J, Feng D, Chu L, Li X, Jin Z, Lin Z, Zeng Q: Role of extracellular signal-regulated kinase, p38 kinase, and activator protein-1 in transforming growth factorbetal-induced alpha smooth muscle actin expression in human fetal lung fibroblasts in vitro. Lung 2006;184:33-42.

179 Kapoun AM, Gaspar NJ, Wang Y, Damm D, Liu YW, O’Young G, Quon D, Lam A, Munson K, Tran TT, Ma JY, Murphy A, Dugar S, Chakravarty S, Protter AA, Wen FQ, Liu X, Rennard SI, Higgins LS: Transforming growth factor-beta receptor type 1 (TGFbetaRI) kinase activity but not p38 activation is required for TGFbetaRI-induced myofibroblast differentiation and profibrotic gene expression. Mol Pharmacol 2006;70:518-531.

180 Shi Y, Patel S, Niculescu R, Chung W, Desrochers $\mathrm{P}$, Zalewski A: Role of matrix metalloproteinases and their tissue inhibitors in the regulation of coronary cell migration. Arterioscler Thromb Vasc Biol 1999; 19:1150-1155.

181 Shi Y, Pieniek M, Fard A, O’Brien J, Mannion JD, Zalewski A: Adventitial remodeling after coronary arterial injury. Circulation 1996;93:340-348.

82 Sakata N, Nabeshima K, Iwasaki H, Tashiro T, Uesugi N, Nakashima O, Ito H, Kawanami T, Furuya K, Kojima M: Possible involvement of myofibroblast in the development of inflammatory aortic aneurysm. Pathol Res Pract 2007;203:21-29. 